\title{
The Trump Administration and International Law
}

\author{
Harold Hongju Koh*
}

\begin{abstract}
Will Donald trump international law? Since Trump's Administration took office, this question has haunted almost every issue area of international law. In his 2017 Foulston Siefkin Lecture, Professor Harold Hongju Koh, former Legal Adviser of the U.S. Department of State, argues that Trump does not own these areas, which are influenced by a pervasive transnational legal process in which many other actors participate. The Lecture shows how those opposing Trump's policies in his administration's first year have successfully triggered transnational legal process as part of a collective counter-strategy akin to Muhammad Ali's famous "rope-a-dope." The Lecture's tour d'horizon illustrates the many techniques that the other participants in this process have used to blunt Trump's early initiatives across a broad array of issue areas. While this counter-strategy has been wearing, the Lecture concludes that the high stakes make continuing the struggle both worthwhile and necessary.
\end{abstract}

* Sterling Professor of International Law and co-founder, Rule of Law Clinic, Yale Law School; Legal Adviser, U.S. Department of State, 2009-13; Assistant Secretary of State for Democracy, Human Rights, and Labor, 1998-2001. What follows is an edited and footnoted transcript of the March 31, 2017, Foulston Siefkin Lecture, delivered at Washburn University School of Law in Topeka, Kansas, updated through November 2, 2017. Versions of this lecture were given at Harvard and the Buffalo and University of California at Irvine Law Schools; the Stanford Handa Center on Human Rights; the Lowy Institute of Sydney, Australia; Christ's College, Cambridge; and the Blavatnik School, Oxford. As noted below, parts of the discussion derive from earlier writings. I thank Dylan Kolhoff, Catherine McCarthy, and Mitzi Steiner of Yale Law School, for their excellent research assistance. Let me express special gratitude to Dean Thomas Romig, the Foulston Siefkin law firm, and my good friend Professor Craig Martin and his Center for International and Comparative Law for hosting me in Topeka. I am deeply grateful to Lea Brilmayer, Paul Dean, Joel Goldstein, Avril Haines, Steve Herz, Michael Ignatieff, Rebecca Ingber, Steve Koh, Sarah Labowitz, Elisa Massimino, Jim O'Brien, Mike Posner, David Pozen, Charlie Savage, Phil Spector, Julia Spiegel, Todd Stern, and David Zionts for their helpful comments; to Claire Hillman, Cristen Hintze, and James Latta of the Washburn Law Journal for their fine editing; and to my friends and commentators David Sloss, Peggy McGuinness, and Clare Francis Moran, for all they have done to make this Symposium possible. 


\section{Table of Contents}

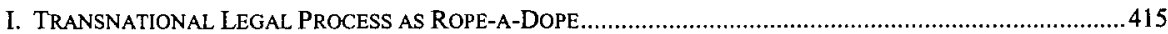

II. Transnational Legal Process in Action: The Counter-Strategy Illustrated ........................422

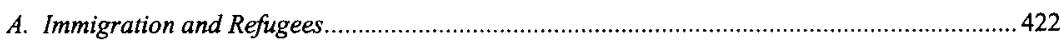

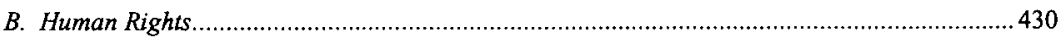

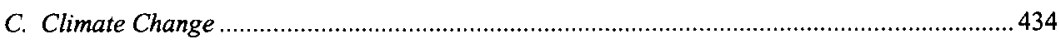

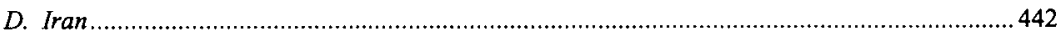

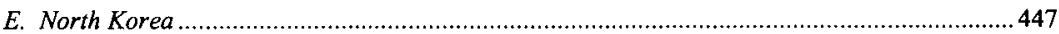

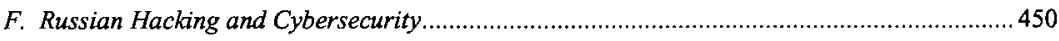

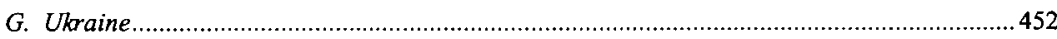

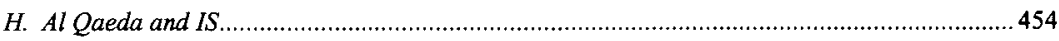

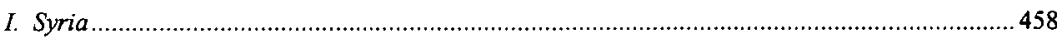

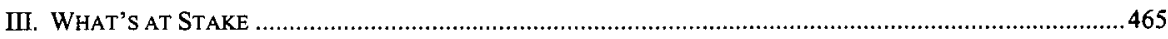

It is a pleasure to deliver this Foulston Siefkin Lecture here at Washburn School of Law in Topeka, Kansas, the historic scene of Brown v. Board of Education. ${ }^{1}$ I was born the year Brown was decided, and my career has since divided into four lifestreams: thirty-five years as a law professor; nearly thirty as a human rights lawyer; five as a Dean; and ten in the United States government, serving in the Reagan Justice Department's Office of Legal Counsel, then in the Clinton and Obama Administrations' State Departments, first as Madeleine Albright's Assistant Secretary for Democracy, Human Rights, and Labor and later as Hillary Clinton's Legal Adviser. As a supporter of Secretary Clinton for President, I obviously did not vote for our current President, but neither do I wish him ill. But I do expect him to follow his oath, which is to preserve, protect, and defend the Constitution and laws of the United States of America. These include the President's constitutional duty to take care that the laws be faithfully executed, including certain rules of international law, which as ratified treaty or customary international law comprise part of the law of the United States.

At this writing, the Trump Administration has been in office for a little over nine months, a tumultuous period that has disrupted the world of international law. A looming question is whether the Trump Administration's many initiatives will permanently change the nature of America's relationship with international law and its institutions. Is there a counter-strategy to increase the odds that those international obligations will be faithfully executed?

This Lecture will argue first that there is such a counter-strategy--the same theory that I have been applying for most of my professional career, 
both as a scholar and as a practitioner: Transnational Legal Process. ${ }^{2}$ Second, that during the first half-year of the Trump Administration, we have been watching this counter-strategy play out, by transnational actors both inside and outside the U.S. government, to mitigate the Trump Administration's efforts to break, stretch, or violate international law. Third, what is ultimately at stake is a struggle between competing visions of a future world order. In the short term, this unfolding counter-strategy is an appropriate response to curb the new Administration's excesses and to preserve America's constitutional obligations to comply with binding international standards. But more fundamentally, this approach serves as an important counter-measure to prevent the slow backsliding of our Kantian postwar system into a more cynical, Orwellian system of global governance far less respectful of democracy, human rights, and the rule of international law.

\section{TRansnational Legal Process as RoPe-A-DoPE}

The United States of America-and its President in particular-are powerful players in the making and unmaking of international law. But the basic idea underlying Transnational Legal Process is that international law is no longer just for nation-states or national governments. What Jeremy Bentham once called "inter-national law"- the law between and among sovereign nations - has evolved into a hybrid body of international and domestic law developed by a large number of public and private transnational actors. These sovereign and nonsovereign actors include our allies; states, municipalities, and localities of the United States; government bureaucracies; the media; courts; nongovernmental organizations (NGOs); intergovernmental organizations (IGOs); and committed individuals. I have argued that these many actors make and remake transnational law-the hybrid law that combines domestic and international, public and private law-by generating interactions that lead to interpretations of international law that become internalized into, and thereby binding under, domestic (in this case, United States) law. These internalized rules create default patterns of international law-observant behavior for all participants in the process. Those default patterns become routinized, "sticky," and thus difficult to deviate from without sustained effort.

The central insight of this analysis is that most compliance with law comes not from coercion, but from patterns of obedience. ${ }^{3}$ Even all alone at 2 o'clock in the morning, most of us still stop for a red light. Why? Because

2. See generally Harold Hongju Koh, How Is International Human Rights Law Enforced?, 74 IND. L.J. 1397 (1999); Harold Hongju Koh, Is International Law Really State Law?, 111 HARV. L. REV. 1824 (1998); Harold Hongju Koh, Why Do Nations Obey International Law? 106 YALE L.J. 2599 (1997); Harold Hongju Koh, Transnational Legal Process, 75 NEB. L. REV. 181 (1996).

3. To say this, of course, is not to deny that under some circumstances, coercive techniques can and do play an important role in enforcing legal norms. For examples, see generally FrEDERICK SCHAUER, THE FORCE OF LAW (2015). 
most legal compliance does not owe to the fact that a police car is sitting behind you. The prime reason why law-abiding people don't regularly steal from each other is not because it's illegal, or because they fear detection, but because they have internalized a norm, probably learned from their parents, in school or at church, that ethical and law-abiding people do not steal. Internalized norms, not coercion, are the main drivers of legal obedience. ${ }^{4}$ Most legal obedience, I would argue, comes from such norm internalization. And norm internalization can come from many sources, the most prominent being religion, the paradigmatic internalized norm set. Once norms have been internalized by individuals and institutions, they become habits that, once learned, are not easily abandoned. Just as boats sail between riverbanks established by decades of flowing water, and travelers tend to observe established traffic lanes, human and institutional behavior tends to follow default patterns set by internalized norms.

But neither are default habits immutable; with concerted effort, they can be changed. In my own lifetime, many Americans used to smoke regularly indoors, discard plastics in regular trash bins, and leave their seat belts unbuckled. But if, at this lecture, you are drinking from a plastic bottle, you have probably internalized a different habit, which is to throw recyclables into a recycling bin. Why? Because everywhere you go in this building you encounter a sign, read a warning, see a green recycle bin, are confronted by a friend, or are forced to answer a challenge-all interactions that make clear that what you used to do out of laziness or indifference no longer represents appropriate behavior. But most likely, you now recycle because a history of such interactions has gradually internalized within you a new normative interpretation: a period of socialization over time has now taught you to think it is right to recycle. ${ }^{5}$ A series of interactions has clarified a new norm of desirable behavior that you have accepted as part of your internal value set. If most compliance comes from obedience, and most obedience comes from norm internalization, then most norm internalization comes from such interactions, which have led to interpretations that have led to internalizations.

So how does this theory become counter-strategy? If asked, "Do you believe in the power of transnational legal process?" I would answer-like my old teacher Abe Chayes' Southern Baptist minister- "Believe in it? I've seen it done!" Throughout my career, I have seen this strategy applied repeatedly by players both inside and outside of the government. Indeed, as a human rights lawyer, I have tried to apply it myself from outside the government; as a government official, I tried to apply it from within.

Nongovernmental actors can apply the "outside strategy"-_"Interaction-

4. See generally TOM R. TYLER, WHY PEOPLE OBEY THE LAW (1990). note 2 .

5. See generally Harold Hongju Koh, How Is International Human Rights Law Enforced?, supra 
Interpretation-Internalization"- to generate interactions that force interpretations that promote internalizations of international norms even by resisting governments. Lawsuits are the paradigmatic example: if a government policy moves in a legally noncompliant direction, an outside nongovernmental group can sue (generate an interaction) that yields a judicial ruling (an interpretation) that the government defendant must then obey as a matter of domestic law (norm internalization).

The inside strategy, which I applied as a government official, I called "Engage-Translate-Leverage," or simply, using "International Law as Smart Power." In hindsight, call this "the Obama-Clinton doctrine." President Barack Obama tried to apply this foreign policy philosophy throughout his presidency. Upon taking office in 2009, President Obama said that "A new era of engagement has begun," emphasizing that "living our values doesn't make us weaker. It makes us safer, and it makes us stronger."6 That approach was particularly urged upon him by his first Secretary of State, Hillary Rodham Clinton, who argued: "We must use what has been called smart power, the full range of tools at our disposal-diplomatic, economic, military, political, legal, and cultural" to achieve better policy outcomes. ${ }^{7}$ Had she been elected President, Secretary Clinton undoubtedly would have continued that approach.

This strategy means, first, that given the choice, the United States--and other like-minded states-should choose engagement over unilateralism. When faced with a foreign policy problem, the United States should not proceed alone but rather seek to engage with other countries and adversaries around common values, in search of diplomatic solutions that can be embedded within durable international law principles.

Second, a strategy of "international law as smart power" suggests that wherever possible, the United States should choose a persuasive legal translation over denying the applicability of law altogether. If a country faces an entirely new situation - for example, problems that simply did not exist when the international laws of war were first drafted, such as drone warfare or cyber conflict-a tempting, but wrong, approach would be simply to deny the applicability of law, i.e., to ask the "Tina Turner question": "What's law got to do with it? What's law but a sweet old-fashioned notion?" Since we face a new technological situation, some might reason, we must be in a "law-free zone" where we can do whatever we want. Under this reasoning, there is no

6. President Obama's Address to Congress, N.Y. TIMES (Feb. 24, 2009), http://www.nytimes.com/2009/02/24/us/politics/24obama-text.html [http://perma.cc/WT94-Q2RT].

7. Senate Confirmation Hearing: Hillary Clinton, N.Y. TIMES (Jan. 13, 2009), http://www.nytimes.com/2009/01/13/us/politics/13text-clinton.html [http//perma.cc/MY73-WFLX]. See, e.g., Hillary Rodham Clinton, U.S. Sec'y of State, Remarks at the John Jay School of Criminal Justice: Smart Power Approach to Counterterrorism (Sept. 9, 2011), https://20092017.state.gov/secretary/20092013clinton/rm/2011/09/172034.htm [http://perma.cc/MC2X-T5ZQ]. See generally Hillary Rodham Clinton, HaRd ChOICES (2014). 
law to apply because we are in a "legal black hole."

But the better, smart-power alternative is for a government to apply what Montesquieu called the "spirit of the laws," or a "translation approach."8 True, we may not have a set of established legal rules that map perfectly onto the new and unanticipated factual circumstance, but we can still make a goodfaith effort to translate from the spirit of existing rules of law to new situations. $^{9}$ As a policy matter, the translation approach is superior because lawabiding nations strive to act not based on power or expedience alone, but rather, to cabin their new activity within existing, recognizable legal frameworks.

There is a world of difference between saying that we are facing a new situation where there is no law to apply and saying that the existing rules do not exactly cover this new situation, but we are trying in good faith to translate the spirit and intent of existing laws to govern it. In the former circumstance, we are saying that we can make up our own rules and no third party can judge us. But in the latter circumstance, we acknowledge the need to join with others committed to the rule of law to frame a new set of rules that can eventually enjoy international consensus and, ultimately, legal legitimacy. If a more "law-friendly" path exists, "we should follow it, because doing so will keep the law on our side, keep us on the moral high ground, and preserve the vital support of our allies and international institutions as the crisis proceeds." 10

The third element of the inside strategy is a commitment to leveraging international law as smart power. This means blending legal arguments with other tools-including military force, diplomacy, development, technology, markets, and international institutions-to achieve complex sustainable foreign policy outcomes that cannot be achieved without the legitimacy that international law bestows: think the Dayton Peace Accord, the New START treaty, or the Paris Climate Change Agreement. Take, for example, the classic study called The Rise and Fall of the Great Powers by my Yale colleague, historian Paul Kennedy. ${ }^{11}$ History teaches, Kennedy argued, that any great power that tries repeatedly to dominate the world with hard military or economic force will eventually find that force "tapped out," or exhausted. Great

8. Baron de Montesquieu, The Spirit of The Laws (Thomas Nugent trans., 1st ed., 1900). See also Harold Hongu Koh, The Spirit of the Laws, 43 HARV. INT'L L.J. 23 (2002).

9. Cf. Lawrence Lessig, Fidelity in Translation, 71 TEX. L. REV. 1165 (1993) (arguing that any complete account of interpretation must "translate," by allowing for changes in readings even when there has been no change in the document's text).

10. Harold Hongju Koh, Preserving American Values: The Challenge at Home and Abroad, in THE Age of TerRor: AMERICA AND THE WORLd AFTER SEPTEMBER 11, at 143, 153 (Strobe Talbott and Nayan Chanda eds., 2001) ("[W]hich of the available courses of action most closely comports with both the spirit and the letter of the law? If there is such a 'law-friendly' course, we should follow it, because doing so will keep the law on our side, keep us on the moral high ground, and preserve the vital support of our allies and international institutions as the crisis proceeds.").

11. Paul Kennedy, The Rise and Fall of the Great Powers (1989). 
powers tend to overexert their hard power and fall into a situation of "imperial overstretch," plagued by external debt, national exhaustion, and internal dissension. They try to do too much with too little, seeking to motivate the actions of others with tools of coercion rather than persuasion, when in fact most international cooperation comes not from coercion but from joint action motivated by shared values. As we have seen in recent years, even a global superpower like the United States possesses only a limited amount of hard power that can be overtaxed-for example, by simultaneous military campaigns in Iraq, Afghanistan, and Syria.

The more successful and durable approach, political scientist Joseph Nye has argued, is for wise nations to seek to influence the world through "smart power"12 - a combination of "hard" and "soft" power that gains legitimacy from espousing international law and common values. If a nation squanders its reputation for legitimacy, it devalues its greatest asset in exercising global leadership. That is why we seek to make and keep, not gratuitously break, international rules: because those rules hold together the fabric of our multilateral relationships with our allies, international organizations, and other standing institutions of international law.

A moment's reflection tells us that the two strategies are complementary. An outsider's strategy of using "interaction-interpretation-norm internalization" to promote international legal compliance within resisting governments can be combined with an insider's strategy of "engage-translate-leverage" to embed and preserve respect for international law within U.S. governmental bureaucracies. Interaction promotes engagement; interpretation generates translations; and norm internalization ensures and enables lawful options to be leveraged with other policy tools into broader, more creative, and more durable policies. Thus, these two strategies working together - the former implemented by committed nongovernmental activists, the latter by governmental officials committed to the rule of law ${ }^{13}$ - can lead us into a pattern of default compliance with international law that makes casual deviation from these rules more difficult than neophytes might believe.

So how does this analysis apply to a new, willful president arriving at the White House with a self-proclaimed radical agenda to change how America engages the world? In its first year, the Trump Administration has taken a foreign policy approach strikingly hostile to that taken by not only such Democratic Presidents as Bill Clinton and Barack Obama, and Democratic Presi-

12. E.g., Joseph S. Nye, Public Diplomacy and Soft Power, 616 ANNALs OF THE AM. ACAD. OF POL. AND SOC. SCI. 94, 107-08 (2008) ("Power in a global information age, more than ever, will include a soft dimension of attraction as well as the hard dimensions of coercion and inducement. The ability to combine hard and soft power effectively is 'smart power."').

13. I have labeled such outsiders "transnational norm entrepreneurs" and such insiders "governmental norm sponsors," respectively. See Harold Hongju Koh, The 1998 Frankel Lecture: Bringing International Law Home, 35 HoUs. L. REV. 623, 647-48 (1998). 
dential candidates (and Secretaries of State) Hillary Clinton and John Kerry, but also by such past internationalist Republican Presidents as George H. W. Bush and Richard Nixon. ${ }^{14}$

The emerging Trump philosophy seems to be a general rejection of the Obama approach: not "engage-translate-leverage," but rather, "disengageblack hole-hard power." Wherever possible, the Trump instinct seems to be to disengage - unilateralism, or, as he calls it, "America First."15 The Trump approach does not value concerted efforts to translate existing legal rules but rather claims that there are no rules that bind our conduct. Under this worldview, the United States should act based on its perceived national interests, not international rules. The Trump approach seems grounded on claimed national rights, not the universal rights on which this country was founded and that form much of the foundation of modern international law. Finally, the emerging Trump approach seems to rest almost entirely on hard power, offering no visible strategy for bilateral and multilateral diplomatic engagement or any attendant role for the State Department. ${ }^{16}$ Trump and his team have shown little or no inclination to apply an approach that would allow America to leverage the legitimacy of lawful options into a more creative set of proactive solutions to pressing international problems.

As the new Administration takes hold, the obvious question is: who will change whom? Will Trump change international law, or vice versa? The basic message from the theory described above is that no single player in the transnational legal process - not even the most powerful one-can easily discard the rules that we have been following for some time. If players outside and inside the government enforce existing legal constraints in a way that makes policy changes and institutional exits too difficult or politically costly, a mercurial president like Donald Trump may decide to just "move on"-to claim that he has "checked the box" on a political promise and now needs to focus on other issues that he and his political base care more about, such as tax or infrastructure reform.

If all of this seems too academic, just recall "Rope-a-Dope," the famous counter-strategy developed by our greatest pugilistic strategist, Muhammad Ali. Faced in Zaire by George Foreman - a much younger, stronger, seemingly invincible champion-Ali settled upon a brilliantly simple counterstrategy. He surprised everyone by retreating to the ropes and letting the champion pound him, taking pains only to avoid getting knocked out himself.

14. After September 11, George W. Bush, like Donald Trump, headed sharply toward a strategy of "disengage-black hole-hard power," but he visibly reverted toward the use of smart power by the time he left office.

15. President Donald J. Trump, The Inaugural Address, White HousE (Jan. 27, 2017), https://www.whitehouse.gov/inaugural-address [http://perma.cc/GLT5-766E].

16. See generally Robbie Gramer, Dan De Luce \& Colum Lynch, How the Trump Administration Broke the State Department, FOREIGN POL'Y (July 31, 2017), http:/foreignpolicy.com/2017/07/31/how-thetrump-administration-broke-the-state-department/ [http://perma.cc/6PYG-PM65]. 
For many rounds, Ali let his opponent "punch himself out," until, in the late rounds, Ali finally came off the ropes and knocked out his now exhausted and weakened opponent.

The analogy here should be clear. If the Trump Administration threatens to violate international law, actors outside the federal government can apply the external strategy of "interaction-interpretation-internalization" to hold it accountable. ${ }^{17}$ Those opposing President Trump's policy initiatives on legal grounds can use the various fora available to them to resist those initiatives, forcing Trump to punch himself out by expending energy and capital on initiatives that do not advance his or his party's chances at reelection. Meanwhile, U.S. bureaucrats committed to international rules can continue to pursue a strategy of engage-translate-leverage to maintain default compliance with existing norms, unless explicitly directed to do otherwise. ${ }^{18}$ Outside activists can work with other players who are checking the White House to generate interactions via direct democracy, citizen mobilization, litigation, advocacy, and resistance. If the federal government fails to follow international law, states and localities - as both outsiders and insiders - can step up to help fill the gap. ${ }^{19}$

This struggle can continue until one side or another gets exhausted. But those in today's "Resistance" are making much the same strategic bet as Ali made in Zaire: that over time, the blustering player who loudly launches multiple ineffectual initiatives to change the status quo will force little real change; get tired, exhausted, and frustrated from all the flailing around; and ultimately find himself getting politically "knocked out."

17. See Clare Francis Moran, Crystallizing the International Rule of International Law: Trump's Accidental Contribution to International Law, 56 WASHBURN L.J. 491 (2017).

18. For a recent example, see the Pentagon's response to President Trump's tweet announcing a "Transgender Ban" in the U.S. military. Indrees Ali \& Phil Stewart, Top U.S. General Says No Changes Yet to Transgender Policy, ReUTERs (July 27, 2017, 2:45 PM) ("'There will be no modifications to the current policy until the President's direction has been received by the Secretary of Defense and the Secretary has issued implementation guidance,' [Joint Chiefs Chair] Dunford said in the written message to service chiefs, commanders and senior enlisted leaders ...."), https:/www.reuters.com/article/usa-military-transgenderidUSL1N1KI13U [http://perma.cc/B24H-EEAV]. At this writing, the Transgender Ban in the military remains "under review." Bill Chappell, Mattis Puts Hold on Transgender Ban for Current Military Service Members, NPR (Aug. 30, 2017, 9:33 AM), http:/www.npr.org/sections/thetwoway/2017/08/30/547258742/mattis-puts-hold-on-transgender-ban-for-current-military-service-members [http://perma.cc/4S78-9E8X]. Meanwhile, several lawsuits have already been brought to challenge the legality of the Ban. See, e.g., Karnoski v. Trump, No. 2:17-cv-01297 (W.D. Wash. filed Aug. 28, 2017); Stone v. Trump, No. 1:17-cv-02459-MJG (D. Md. filed Aug. 28, 2017).

19. For analysis of the possible federalism challenges to state and local efforts at climate diplomacy, see David Sloss, California's Climate Diplomacy and Dormant Preemption, 56 WASHBURN L.J. 507 (2017). 


\section{Transnational Legal Process in ACtion: ThE COUNTER-STRATEGY ILLUSTRATED}

This rope-a-dope approach describes the broader counter-strategy of "transnational legal process" that we have seen play out across the broad spectrum of U.S. foreign policy during the first year of Donald Trump's presidency. At the risk of trying to describe a landscape from a moving train, let me illustrate by discussing many interactions witnessed over a broad range of issue areas.

Donald Trump was inaugurated as President on January 20, 2017. The next day, millions marched in protest in cities around the world, all chanting "this is what democracy looks like." Then came the executive orders, starting with the Travel Ban.

\section{A. Immigration and Refugees}

Perhaps the most visible face of the Trump Administration's international policies has been its harsh stance on immigration, including three travel bans; an order seeking to strip all federal funding from so-called sanctuary cities $^{20}$; strict border controls, as illustrated by repeated calls for a wall allegedly to be paid for by the Mexican government ${ }^{21}$; stated hostility toward refugees and the courts; an aggressively maximalist penchant for deportation, even of "Dreamers"22; "shock and awe" raids in schools and in homes to encourage

20. On January 25th, President Trump signed an executive order that sought to withdraw all federal funding from jurisdictions his administration deemed to be "sanctuaries," a term nowhere defined in the order and apparently used to coerce localities into adopting the aggressive federal immigration agenda. The County of Santa Clara and the City and County of San Francisco sued to challenge the constitutionality of the order and to block its implementation. The jurisdictions argued that the President was attempting to usurp a spending power he does not possess under the Constitution and that the order violated the Due Process and Tenth Amendment rights of the localities. The U.S. District Court for the Northern District of California agreed, temporarily enjoining nationwide the order's key defunding provision. See Cty. of Santa Clara v. Trump, No. 17-CV-00485-WHO, 2017 WL 1459081 (N.D. Cal. Apr. 25, 2017), reconsideration denied, No. 17-CV-00485-WHO, 2017 WL 3086064 (N.D. Cal. July 20, 2017). See generally Russell Spivak, Case Summary: Federal District Court Issues Nationwide Injunction Against Trump's Sanctuary City Executive Order, LAWFARE (Apr. 26, 2017, 11:45 AM) https://www.lawfareblog.com/case-summary-federal-districtcourt-issues-nationwide-injunction-against-trumps-sanctuary-city [http://perma.cc/QZ7P-D99H].

21. But see the remarkable anti-Wall Super Bowl commercial by 84 Lumber. 84 Lumber, 84 Lumber Super Bowl Commercial - The Entire Journey, YouTUBE (Feb. 5, 2017),

https://www.youtube.com/watch?v=nPo2B-vjZ28 [http://perma.cc/5EPY-7UZR].

22. Section 5 of the Executive Order on Sanctuary Jurisdictions sets out the Administration's expansive deportation priorities, which include giving immigration officers broad authority to deport any non-citizen suspected, in that officer's opinion, of posing a "safety risk." On September 5, 2017, President Trump further announced that he would repeal President Obama's Deferred Action on Childhood Arrivals (DACA) program, which grants work permits to about 800,000 undocumented immigrants brought to the United States as children, but that he would delay its end for six months to give Congress time to pass legislation to replace it. See Jennifer Rubin, Ending DACA Would Be Trump's Most Evil Act, WASH. POST (Sept. 4, 2017), $\mathrm{https} / /$ www.washingtonpost.com/blogs/right-turn/wp/2017/09/04/trump-ending-daca-would-be-crueltywrapped-in-a-web-of-lies/ [http://perma.cc/YMV9-UKP9]. Yale Law School's Worker and Immigrant Rights Advocacy Clinic and a number of states swiftly filed suit seeking to enjoin the President's executive 
"self-deportation"; announced plans to cut legal immigration in half ${ }^{23}$; and, most glaringly, a willingness to bomb out of professed sympathy for the very same Syrian children that the Administration refuses to admit into the United States.

On January 27, 2017, President Trump signed his most visible executive order: the Travel Ban that for ninety days blocked entry into the United States by citizens of seven predominantly Muslim countries (in March reduced to six, and in September adjusted to six majority-Muslim countries, plus North Korea and Venezuela) and barred individuals with valid visas and green cards from those countries from re-entering the United States. ${ }^{24}$ For 120 days, the Ban suspended entry of all refugees into the United States, and for an indefinite period of time it barred all Syrian refugees. This Travel Ban thus seemed like a thinly disguised Muslim Ban, not least because the President had repeatedly promised to impose such a measure on the campaign trail. ${ }^{25}$

On its face, such a policy seemed blatantly illegal. First, ours is a country founded on religious freedom. Even a sanitized Muslim Ban discriminates against one religion, de facto preferencing others, in violation of domestic law. Such a broad ban has never been authorized by statute; to the contrary, immigration laws forbid exclusion based on national origin. Second, under international law, such a ban facially violates two treaties to which the U.S. has long been a party: the Refugee Convention, ${ }^{26}$ which requires that " $[t]$ he Contracting States shall apply the provisions of this Convention to refugees without discrimination as to race, religion or country of origin," as well as the International Covenant on Civil and Political Rights, which states that "[a]11 persons are equal before the law and are entitled without any discrimination to the equal protection of the law." 27 Third, the Ban was both over- and underinclusive. While none of the countries from which people were excluded had actually ever produced a terrorist who had killed anyone on U.S. soil, other

action. WIRAC Challenges Trump Administration's Termination of DACA, YALE L. SCH. (Sept. 5, 2017), $\mathrm{https}$ //law.yale.edu/yls-today/news/wirac-challenges-trump-administrations-termination-daca

[http://perma.cc/8QZ6-FQPN].

23. See Reforming American Immigration for Strong Employment Act, S. 354, 115th Cong. (2017)

24. Protecting the Nation from Foreign Terrorist Entry into the United States, 82 Fed. Reg. 8977 (Jan. 27, 2017).

25. E.g., Sonam Sheth, Trump Campaign Deletes Statement on Muslim Ban After Reporter Asks About It, BUS. INSIDER (May 8, 2017, 3:27 PM), http://www.businessinsider.com/trump-campaign-muslim-banstatement-website-2017-5 [http://perma.cc/Q9FM-AXF8].

26. Convention Relating to the Status of Refugees art. 3, July 28, 1951,189 U.N.T.S. 150. See also comments by Trump adviser Rudy Giuliani describing how he was asked to implement a Muslim Ban. Amy B. Wang, Trump Asked for a 'Muslim Ban, 'Giuliani Says - and Ordered a Commission to Do It 'Legally", WASH. POST (Jan. 29, 2017), https://www.washingtonpost.com/news/the-fix/wp/2017/01/29/trump-asked-fora-muslim-ban-giuliani-says-and-ordered-a-commission-to-do-it-legally [http:/perma.cc/7HJB-JJQ6]; Scott Horsley, Trump's Latest Tweets on Travel Ban Could Raise New Legal Hurdles, NPR (June 5, 2017, 9:40 AM), http://www.npr.org/2017/06/05/ 531558813/trumps-latest-tweets-on-travel-ban-could-raise-new-legalhurdles [http://perma.cc/5VX4-SCGH].

27. International Covenant on Civil and Political Rights art. 26, Dec. 9, 1966, 999 U.N.T.S. 171 (ratified June 8, 1992). 
countries (e.g., Saudi Arabia, from which most of the 9/11 attackers hailed) were not on the list. ${ }^{28}$

Fourth, the President had repeatedly called for a system of "extreme vetting." But he seemed not to appreciate that we already have a system of extreme vetting, conducted on an intensive, individualized basis. Far from being ineffective, that system has been working, as demonstrated by the fact that no individual vetted through the rigorous system regulating the entry of refugees has committed a fatal terrorist act in our country for more than forty years. ${ }^{29}$ The new Administration proposed instead to replace individualized vetting with categorical exclusions based on national and religious stereotypes. But under our Constitution, group-based exclusions are illegal when based on such crude categorizations. Such stereotyping offends a basic American article of faith: that we judge people not by where they are from, or by the color of their skin, or by the deity they worship, but by the content of their individual character. As I learned from many sad hours of studying terrorist profiles, some proven terrorists fit no group stereotype, while other individuals who may fit a stereotype could instead prove to be gold-star fathers of American soldiers. Fifth, the Travel Ban emerged from a grossly defective governmental process. As it was rushed into operation, the executive order was not vetted by knowledgeable governmental lawyers, the incoming Secretaries in the Departments of Defense and Homeland Security, or most of the key legislators who oversee counterintelligence and homeland security issues. ${ }^{30}$

Sixth, and most glaringly, the sudden, overbroad Travel Ban responded to no new national security threat, a fact that I confirmed with a number of former government colleagues who had served in the most sensitive national security positions until Inauguration Day, January 20, 2017. They all agreed that they knew of no new security threat-and the new Administration had identified none- that warranted sharply shifting toward an overtly discriminatory policy only seven days later. I found a large number of former national security officials of both political parties ready to attest that the Travel Ban bore no rational relation to any compelling governmental interest.

28. Protecting the Nation from Foreign Terrorist Entry into the United States, 82 Fed. Reg. at 8977 ; Brief for Former National Security Officials as Amici Curiae Supporting Plaintiff-Appellees, Int'1 Refugee Assistance Project v. Donald J. Trump, 857 F. 3d 554 (4th Cir. 2017) (No. 17-15589), 2017 WL 1372588.

29. Alex Nowrasteh, Little National Security Benefit to Trump's Executive Order on Immigration, CATO INST. (Jan. 25, 2017, 3:31 PM), https:/www.cato.org/blog/little-national-security-benefit-trumpsexecutive-order-immigration [http://perma.cc/59ZJ-MUPC].

30. Justin Sink \& Ben Brody, U.S. Exempts Green Card Holders from Trump's Travel Ban, BLOOMBERG (Jan. 29, 2017, 5:53 AM), https://www.bloomberg.com/news/articles/2017-01-29/trump-says-us-needs-extreme-vetting-after-action-by-judges [http://perma.cc/ZH3L-ZB67]; Sean Sullivan \& Kelsey Snell, Angry Republicans Lash Out at Trump for Not Consulting Them on Travel Ban, WASH. POST (Jan. 30, 2017), https://www.washingtonpost.com/powerpost/angry-republicans-lash-out-at-trump-for-not-consulting-themon-travel-ban/2017/01/30/3f7db742-e715-11e6-80c2-30e57e57e05d_story.html [http://perma.cc/H6MXWAWY]. 
As transnational legal process kicked in, the Ban came under swift and furious legal challenge. An Iraqi interpreter, Hameed Khalid Darweesh, who had worked with and supported U.S. forces in Iraq, was one of the first people stopped pursuant to the Ban, at John F. Kennedy Airport. His counsel, the Yale Law School Worker and Immigrant Rights Advocacy Clinic supervised by my colleague Professor Michael Wishnie, provoked an interaction that led to a legal interpretation: they successfully filed for a temporary restraining order on Darweesh's behalf in the U.S. District Court for the Eastern District of New York. ${ }^{31}$ Darweesh's counsel then asked the new Rule of Law Clinic that I had just organized at Yale ${ }^{32}$ to develop a declaration on behalf of former national security officials confirming that the Travel Ban would likely harm our counterterrorism and law enforcement efforts, because it was based not on any known national security threat but rather, on illegal stereotypes and prejudice.

As the actions broadened to include a suit brought by the State of Washington in Washington federal court, our Yale Law School Rule of Law Clinic filed first a joint declaration and then an amicus brief on behalf of ten former national security officials: former Secretaries of State Madeleine Albright and John Kerry, former Secretary of Defense Leon Panetta, former Secretary of Homeland Security Janet Napolitano, four former heads of the CIA (including two Republicans, Michael Hayden and John McLaughlin), and the most recent National Security Advisor and her two deputies (Susan Rice, Avril Haines, and Lisa Monaco). A number of these amici were still serving in the government just seven days before this order was issued and swore that they saw no emergent national security threat that justified the sudden policy change.

This outside pressure soon combined with internal resistance. In the State Department, a thousand career officials swiftly signed a dissent channel cable that said: "this ban stands in opposition to the core American and constitutional values that we, as federal employees, took an oath to uphold."33 The cable closed, memorably, by declaring "we are better than this ban." 34 Remarkably, it then became evident that the White House had announced the

31. Darweesh y. Trump, No. 17 CIV. 480 (AMD), 2017 WL 388504 (E.D.N.Y. Jan. 28, 2017).

32. I am particularly grateful to my former State Department colleague Phil Spector for his coleadership of the national security group of our Clinic, to my colleague Hope Metcalf and Darweesh counsel Mike Wishnie, and to our Clinic's founding student directors Denisha Bacchus, Sameer Jaywant, Mitzi Steiner, and Eugene Rusyn. For a description of the Clinic's work in the Travel Ban litigation, see generally Rule of Law Clinic Files Amicus Brief in SCOTUS Travel Ban Case, YALE L. SCH. (Sept. 20, 2017), https://law.yale.edu/yls-today/news/rule-law-clinic-files-amicus-brief-scotus-travel-ban-case [http://perma.cc/P3DY-EYHR].

33. Dissent Channel Memorandum to Edward J. Lacey, Acting Director of Pol'y Planning, Alternatives to Closing Doors in Order To Secure Our Borders (Jan. 2017), https://www.washingtonpost.com/r/2010/2019 /WashingtonPost/2017/01/30/Editorial-Opinion/Graphics/Draft_Dissent_on_EOSec3.pdf [http://perma.ce/Y6BT-A67M].

34. Id. 
Ban without actually knowing whether the Justice Department was prepared to defend it in court. When ordered to do so, Acting Attorney General Sally Yates refused, for which she was fired and accused by the President of having "betrayed the Department of Justice." 35 In short order, more than thirty cases were filed in the First, Second, Fourth, and Ninth Circuits. As the legal battles progressed, the intelligence community and other parts of the bureaucracy apparently engaged in unprecedented leaking, providing more grist for the lawsuits. ${ }^{36}$ As the cases unfolded, the Executive Order was repeatedly blocked, at which point the Administration retracted the first travel ban and announced its intent to review and re-release it later.

In the meantime, other players in the transnational legal process joined the fray. Our allies, including Germany's Angela Merkel, Canada's Justin Trudeau, 37 Britain's Theresa May, France's Emmanuel Macron, Australia's Malcolm Turnbull, and many other members of the G-20, all raised the issue directly in early conversations with the new President. Pressed by such groups as Veterans for American Ideals, ${ }^{38}$ members of the U.S. military protested, particularly when it became clear that our Iraqi military allies were being barred from entry. One of the commanding generals of the Iraqi forces, Talib al Kenani, marveled, "I'm a four star general, and I'm banned from entering the U.S.?"39

Domestic actors quickly came forward. Democratic members of Congress-joined by such Republican legislators as Senators John McCain, Lindsey Graham, Bob Corker, Marco Rubio, and Tim Scott, as well as House Homeland Security Chairman Mike McCaul and Representative Charlie Dent-all criticized the Order. Unexpected Republican voices like the Koch brothers, former Vice President Dick Cheney, and conservative former Justice Department lawyer John Yoo all opposed the Ban, suggesting that the decision had driven a wedge between Trump and his traditional conservative al-

35. Sari Horwitz, Who Is Sally Yates? Meet the Acting Attorney General Trump Fired for 'Betraying' the Justice Department., WASH. POST (Jan. 30, 2017),

https:/www.washingtonpost.com/world/national-security/meet-the-acting-attorney-general-fired-by-trumpand-accused-of-betraying-the-justice-department/2017/01/30/05d4478c-e750-1 le6-80c2-

30e57e57e05d_story.html [http://perma.cc/HY7Y-3QDQ].

36. See, e.g., Memorandum from the Dep't of Homeland Security, Citizenship Likely an Unreliable Indicator of Terrorist Threat to the United States (Feb. 2017),

https:/www.documentcloud.org/documents/3474730-DHS-intelligence-document-on-President-Donald.html [http://perma.cc/DH7E-BJEA].

37. Indeed, the Canadians offered temporary residence to anyone stranded in Canada by the Order. Ashifa Kassam, Canada To Offer Temporary Residence to Those Stranded by Trump Travel Ban, GUARDIAN (Jan. 31, 2017, 10:59 AM), https:/www.theguardian.com/world/2017/jan/31/canada-trump-travel-bantemporary-residence [http://perma.cc/98YU-FHJD].

38. Vets4AmericanIdeals (@Vets4AmerIdeals), TwITTER, https://witter.com/Vets4AmerIdeals [http://perma.cc/CP6A-Y8MQ].

39. Charlie D'Agata, Iraqi General Who Works with American Military Kept from Visiting U.S., CBS NEws (Jan. 30, 2017, 7:30 PM), www.cbsnews.com/news/iraqi-general-who-works-with-american-militarykept-from-visiting-u-s/ [http:/perma.cc/A69A-GHRP]. 
lies. ${ }^{40}$ Fifteen State Attorney Generals protested not just the Travel Ban but also Trump's plan to build a wall, to renew deportations, and to punish sanctuary cities. ${ }^{41}$ Dozens of cities and counties filed an amicus brief supporting the individual and subnational plaintiffs. ${ }^{42}$ Forty-seven universities, including my home university, Yale, spoke out against the $\mathrm{Ban},{ }^{43}$ and 163 tech companies filed an amicus brief protesting how the Travel Ban would affect their workers. ${ }^{44}$

Within hours, the resistance had spread beyond the courts to the streets. Armed by the internet, lawyers sprang into action. Because the initial lawsuit filed by Yale's WIRAC Clinic took the form of a habeas class action, certification of the class allowed every immigrant blocked at the airport to say they were entitled to their own lawyer. More than 4000 volunteer lawyers across America rushed to their nearest international airport, showing officials court orders that they had downloaded to their cellphones and iPads and filing habeas petitions based on legal templates that our students had uploaded. ${ }^{45}$ As taxi, Uber, and Lyft drivers continued to deliver more lawyers, the airports became centers of protest, with spontaneous demonstrations erupting in dozens of airports only one week after widespread demonstrations had transpired in city streets. Acts of solidarity broke out all across America, including individual protests, group marches, and community candlelight vigils. Popular culture joined in: the Museum of Modern Art and its exhibits displayed art by individuals from the excluded countries; Saturday Night Live and late-night comedians attacked the Ban; traditional and social media highlighted the human impact of the Ban in separating families; and stories were virally shared on Facebook, Twitter, Snapchat, and other social media outlets. Even Super Bowl commercials told sympathetic stories about immigrants who came to America to make good, like the founders of the Anheuser-Busch beer dis-

40. Philip Elliott, The Koch Brothers Oppose President Trump's Immigration Ban, TIME (Jan. 29, 2017), http://time.com/4652905/koch-brothers-donald-trump-immigration-Ban-order [http://perma.cc/2FQRB6H2]; Heather Digby Parton, George W. Bush's "Torture Lawyer" Turns on Trump-But It May Be Too Late, SALON (Feb. 7, 2017, 5:15 AM),

http://www.salon.com/2017/02/07/george-w-bushs-torture-lawyer-turns-on-trump-but-it-may-be-too-late [http://perma.cc/AC7W-LFA6]; Justin Wm. Moyer, Dick Cheney Slams Trump's Muslim Entry Ban, WASH. POST (Dec. 8, 2015), https://www.washingtonpost.com/news/morning-mix/wp/2015/12/08/dick-cheneyslams-trumps-muslim-entry-ban-and-suggests-u-s-re-invade-middle-east [http://perma.cc/A2NK-KFKU].

41. Dan Levine, Attorneys General from 15 U.S. States, DC Decry Immigration Order, REUTERS (Jan. 29, 2017, 12:38 PM), http:/www.reuters.com/article/us-usa-trump-attorneygenerals/attorneys-general-from15-u-s-states-dc-decry-immigration-order-idUSKBN15D0XZ [http://perma.cc/PV9G-XN4C].

42. Brief for Chicago, Los Angeles, New York, Philadelphia, and Other Major Cities and Counties as Amici Curiae Supporting Plaintiffs, Hawai'i v. Trump, No. CV 17-00050 DKW-KSC, 2017 WL 1167383 (D. Haw. Mar. 29, 2017).

43. Katie Reilly, University Leaders Call President Trump's Immigration Order a Threat to American Higher Ed, TIME (Feb. 3, 2017), http://time.com/4660098/donald-trump-universities-immigration-ban [http://perma.cc/Z33J-3P24].

44. Brief for Technology Companies as Amici Curiae Supporting Appellees, Hawai'i v. Trump, No. CV 17-00050 DKW-KSC, 2017 WL 1167383 (D. Haw. Mar. 29, 2017).

45. Worker and Immigrant Rights Advocacy Clinic, Legal Templates, YALE L. SCH., (last visited Sept. 30, 2017), https://law.yale.edu/studying-law-yale/clinical-and-experiential-learning/our-clinics/worker-andimmigrant-rights-advocacy-clinic/legal-templates [http:/perma.cc/6YSP-ZNBX]. 
tributorship. ${ }^{46}$ Interest groups took turns staging major demonstrations, including a March for Climate, a March by Scientists, a Day Without Immigrants (when New York diners couldn't get a meal in less than three hours), and a Day Without Women (when little got done anywhere).

By March, the President had issued a second, revised Travel Ban, ${ }^{47}$ which maintained the original Ban's basic features. Our Rule of Law Clinic converted our initial national security declaration into an amicus brief signed by fifty former officials that would eventually be filed at the Supreme Court. ${ }^{48}$ The argument was simple: "It doesn't matter how much lipstick you put on that pig; it's still a pig." A Muslim Ban, however packaged, is still a Muslim Ban. We argued that the revised order was "ill[]conceived, poorly implemented and ill[]explained." 49 We again pointed out that there was no national security justification for this sudden change of policy, which attacked humanitarian values while threatening U.S. jobs. ${ }^{50}$ The revised Ban would endanger our troops in the field, counterterrorism partnerships, and domestic law enforcement and enrage the very Muslim-American communities whose help the U.S. government needs in order to find those individuals who might commit terrorist attacks within the United States. Even if one's goal is extreme vetting, the existing individualized vetting system was plainly superior to a group Ban.

Even before the revised Ban went into effect, it was blocked by district courts in the Fourth and Ninth Circuits. ${ }^{51}$ In the first skirmish before the Supreme Court over a stay of the Ninth Circuit's injunction, Chief Justice Roberts and Justice Kennedy joined the liberal justices - Breyer, Ginsburg, Sotomayor, and Kagan--in a Solomonic per curiam opinion from which Justices

46. Budweiser Focuses on Immigration in Super Bowl Commercial, CHI. TRIB. (Jan. 31, 2017, 6:22 PM), www.chicagotribune.com/sports/football/ct-nfl-super-bowl-advertising-anheuser-busch-spt-20170131story.html [http://perma.cc/GJR8-VX2X].

47. Protecting the Nation from Foreign Terrorist Entry into the United States, 82 Fed. Reg. 13209 (Mar. 6, 2017).

48. See Brief for National Security Officials as Amici Curiae Supporting Respondents at 3-4, Donald J. Trump v. State of Hawai'i (Nos. 16-1436 \& 16-1540) http://www.scotusblog.com/wpcontent/uploads/2017/09/16_1436_16_1540_bsac_Former_National_Security_Officials.pdf

[http://perma.cc/2HYA-GFLP] (arguing that "all available evidence suggests that the Order was not based on national security judgment at all, but rather, on a deliberate political decision to discriminate against a religious minority").

49. Brief for Former National Security Officials, supra note 28.

50. USA Today reports a potential loss of $\$ 18$ billion in tourism revenue this year. Bart Jansen, Trump's Travel Ban Could Cost $\$ 18 B$ in U.S. Tourism, Analysis Shows, USA TODAY (Mar. 29, 2017, 6:01 PM), https:/www.usatoday.com/story/news/world/2017/03/29/trumps-travel-ban-could-cost-18b-us-tourismtravel-analysts-say/99708758/ [http://perma.cc/6DHQ-J2R9].

51. Hawai'i v. Trump, No. CV 17-00050 DKW-KSC, 2017 WL 1167383 (D. Haw. Mar. 29, 2017), hearing in banc denied sub nom. Hawai'i v. Trump, No. 17-15589, 2017 WL 1420813 (9th Cir. Apr. 21, 2017), aff'd in part, vacated in part, remanded sub nom. Hawai'i v. Trump, 859 F.3d 741 (9th Cir. 2017), cert. granted sub nom. Trump v. Int'l Refugee Assistance Project, 137 S. Ct. 2080 (2017); Int'l Refugee Assistance Project v. Trump, No. CV TDC-17-0361, 2017 WL 1018235 (D. Md. Mar. 16, 2017), aff'd in part, vacated in part, 857 F.3d 554 (4th Cir. 2017), as amended (May 31, 2017), as amended (June 15, 2017), cert. granted, 137 S. Ct. 2080 (2017); Washington v. Trump, No. C17-0141JLR, 2017 WL 462040 (W.D. Wash. Feb. 3, 2017), appeal dismissed sub nom. Washington $\mathrm{v}$. Trump, No. 17-35105 (9th Cir. Feb. 4, 2017). 
Thomas and Alito, and new Justice Neil Gorsuch, vociferously dissented. ${ }^{52}$ Initially, the merits of the case were scheduled to be argued before the Supreme Court in October 2017. But just weeks before that argument, the Administration issued yet a third version of its Ban, dropping one country (Sudan) from the list while adding several others (Chad, North Korea, and with respect to some officials, Venezuela), which caused the Court to remove the case from its October argument calendar. ${ }^{53}$

On its face, Travel Ban 3.0 continued to take the same overbroad, blanket approach that the lower courts had previously enjoined, and appeared based more on national stereotypes than on intense individualized vetting. The revision's tweaks seemed designed mainly to lessen the impression that the Ban was targeting Muslim-majority countries-although Chad is, in fact, predominantly Muslim; only a tiny number of North Koreans enter the U.S. every year anyway, most of them refugees; and the targeted Venezuelan officials were not apparently being sanctioned for terrorist activity. ${ }^{54}$ The abrupt change led to the Court declaring both circuit court judgments moot and vacated-although if so treated, the Ban could be constantly revised to block future travel while persistently avoiding judicial review. ${ }^{55}$ Within days, district courts in both the Fourth and Ninth Circuits again enjoined Travel Ban 3.0, raising three obvious questions, to all of which the answer should be no: first, whether the Supreme Court will declare the new cases moot; second, whether a finding of mootness would vacate the decisions below that blocked implementation of Travel Ban 3.0; and third, if the case reaches the merits, whether Chief Justice John Roberts and Justice Anthony Kennedy, the Court's traditional swing man, will vote to sustain the essence of the Ban.

Beneath it all, the real question remains: how much does Donald Trump really care about the Muslim Ban? After all, it has already been shown that the Ban drives a wedge deep within his fragile coalition, between Trumpites and traditional Republicans. Every piece of capital he spends on this issue

52. Trump v. Int'1 Refugee Assistance Project, 137 S. Ct. 2080, 2088 (2017) (narrowing the Travel Ban by stay to bar only those travelers who lacked a "bona fide relationship" to the United States).

53. Michael D. Schear, Ron Nixon \& Adam Liptak, Supreme Court Cancels Hearing on Previous Travel Ban, N.Y. Times (Sept. 25, 2017), https://www.nytimes.com/2017/09/25/us/politics/trump-travelban-supreme-court.html [http://perma.cc/U3VW-P9HD].

54. A Trump Travel Ban We've Seen Before, N.Y. TIMES (Sept. 25, 2017), https:/www.nytimes.com/2017/09/25/opinion/editorials/trump-travel-Ban.html [http://perma.cc/TC7EQCE9].

55. The White House Office of the Press Sec'y, Presidential Proclamation Enhancing Vetting Capabilities and Processes for Detecting Attempted Entry into the United States by Terrorists or Other Public-Safety Threats, WHTE HOUSE (Sept. 24, 2017), https://www.whitehouse.gov/the-pressoffice/2017/09/24/enhancing-vetting-capabilities-and-processes-detecting-attempted-entry

[http://perma.cc/XLE5-CNEW]; Michael D. Shear \& Ron Nixon, Trump's Travel Ban to Be Replaced by Restrictions Tailored to Certain Countries, N.Y. Times (Sept. 22, 2017), https: $/ /$ www.nytimes.com/2017/09/22/us/politics/trump-travel-Ban-replacement-restrictions.html [http://perma.cc/PZZ2-5DKV]. For analysis see Marty Lederman, The New Entry Suspensions and Restrictions: A Synopsis (with Update on SG Letter to Court), JUST SECURITY (Sept. 24, 2017, 8:12 PM), https://www.justsecurity.org/45278/entry-suspensions-restrictions/ [http://perma.cc/J53R-DMKU]. 
takes away from the core agenda that actually interests his coalition: the Obamacare repeal, jobs, tax reform, regulatory rollback, and infrastructure. To date, the coalition's repeated efforts to repeal Obamacare have spectacularly failed, further disrupting the President's coalition and leaving precious little capital for his remaining core issues.

\section{B. Human Rights}

During my adult life, as a law professor, as Legal Adviser, and as Assistant Secretary of State for Democracy, Human Rights, and Labor, I have heard every Secretary of State-whether Democratic or Republican-speak out in support of human rights. ${ }^{56}$ But when asked about human rights in other countries, our newest Secretary of State, Rex Tillerson, repeatedly said at his confirmation hearing that he was "not ready to judge." 57 But how can any responsible U.S. official not be ready to judge, for example, whether innocent people in the Philippines can be summarily executed by their authoritarian President, Rodrigo Duterte? ${ }^{58}$ Secretary Tillerson also announced his intention to support American interests, but not American values. ${ }^{59} \mathrm{He}$ stated, remarkably, that an overreliance on values "creates obstacles to our ability to advance our national security interests [and] our economic interests." 60 By so saying, he reaffirmed Trump's prioritizing of national over universal rights and overlooked decades of bipartisan U.S. policy, which had repeatedly confirmed that advancing global human rights values is in fact a core American interest. ${ }^{61}$

Since then, Tillerson has declined to engage with respect to human rights and has not spoken out in support of universal human rights values in diplomacy with China, Russia, Saudi Arabia, and Turkey. U.N. Ambassador Nikki

56. See generally Harold Hongju Koh, A United States Human Rights Policy for the 21st Century, 46 ST. Louis U. L.J. 293 (2002).

57. Zoë Chapman, The Early Edition: January 13, 2017, JuST SECURITY (Jan. 13, 2017, 7:55 AM), https://www.justsecurity.org/36292/early-edition-january-13-2017 [http://perma.cc/M3WB-EHED]; see also Margaret McGuinness, Paying Lip Service to Human Rights: The Value of Presidential Human Rights Talk, 56 WASHBURN L.J. 471 (2017).

58. Carol Morello, Did Tillerson and Duterte Discuss Human Rights? Depends on Which Side You Ask., WASH, POST (Aug. 8, 2017), https:/www.washingtonpost.com/world/did-tillerson-and-duterte-discusshuman-rights-depends-on-which-side-you-ask/2017/08/08/6eac13af-1046-4bf1-b971-

7a4c8a91e8d1_story.html [http://perma.cc/U6RA-X522].

59. Sec'y of State Rex Tillerson, Remarks to U.S. Department of State Employees (May 3, 2017), https://www.state.gov/secretary/remarks/2017/05/270620.htm [http://perma.cc/7N5X-8YDL] (stating that "we really have to understand, in each country or each region of the world that we're dealing with, what are our national security interests, what are our economic prosperity interests, and then as we can advocate and advance our values, we should ....").

60. Id.

61. For a thoughtful analysis of how Tillerson's approach runs afoul of longstanding Presidential Directive 30, followed by many presidents, see Michael Posner, Tillerson's Degradation of Human Rights Mustn't-and Can't Yet-Be Executive Branch Policy, Just SECuRITY (May 22, 2017, 8:35 AM), https://www.justsecurity.org/ 41229/tillerson-human-rights-presidential-directive-30/ [http://perma.cc/N842-TS58]. 
Haley called the U.N. Human Rights Council "corrupt." ${ }^{2}$ The Secretary of State did not appear at the announcement of the annual Human Rights Report. ${ }^{63}$ The United States no longer appears to defend its conduct at the InterAmerican Human Rights Commission. And there has been a blatant, disturbing softness on human rights in the Middle East, particularly with respect to Saudi Arabia, Egypt, Bahrain, and Turkey, where the President congratulated President Erdogan after a visibly irregular referendum and an attack by Turkish guards on demonstrators outside the Turkish embassy in Washington. Most recently, it has been reported that the State Department plans to drop the promotion of democracy and human rights from its mission statement. ${ }^{64}$ The Administration has plainly lost sight of the many ways in which the United States has traditionally relied on alliances and cooperation with our rightsrespecting democratic allies to help advance our broader national security interests. ${ }^{65}$

Perhaps the most visible proposed human rights rollback was candidate Trump's statement that "[if I am elected, w]e'll use waterboarding and a hell of a lot worse than waterboarding." 66 Shortly after the election, the press leaked a draft national security executive order that called for reinstating the discredited program of interrogation of high-value alien terrorists, to be operated outside the United States, presumably at revived "black sites"-former offshore detention facilities operated by the C.I.A. ${ }^{67}$

But campaign statements and draft executive orders are not law. Congress has repeatedly forbidden torture by treaty and statute. ${ }^{68}$ As a Judge Ad-

62. Somini Sengupta, Nikki Haley Calls United Nations Human Rights Council 'So Corrupt', N.Y. Times (Mar. 29, 2017), https://www.nytimes.com/2017/03/29/world/nikki-haley-un-human-rights-councilcorrupt.html [http://perma.cc/2Q49-UDVS].

63. Michael Gerson, Rex Tillerson Is a Huge Disappointment, Wash. Post (Aug. 7, 2017), https://www.washingtonpost.com/opinions/rex-tillerson-is-a-huge-disappointment/2017/08/07/a9918b8e7ba5-11 e7-9d08-b79f191668ed_story.html [http://perma.cc/5KAV-BYEL].

64. Josh Rogin, State Department Considers Scrubbing Democracy Promotion from Its Mission, WASH. POST (Aug. 1, 2017), https://www.washingtonpost.com/news/josh-rogin/wp/2017/08/01/statedepartment-considers-scrubbing-democracy-promotion-from-its-mission [http://perma.cc/EYZ3-C39Z].

65. See generally Harold Hongju Koh, A United States Human Rights Policy for the 21st Century, supra note 56; Michael Posner, Trump Abandons the Human Rights Agenda, NEw YORKER (May 26, 2017), https://www.newyorker.com/news/news-desk/trump-abandons-the-human-rights-agenda [http://perma.cc/72ME-L3K5].

66. Jenna Johnson, Trump Says 'Torture Works,' Backs Waterboarding and 'Much Worse', WASH. PosT (Feb. 17, 2016), https://www.washingtonpost.com/politics/trump-says-torture-works-backswaterboarding-and-much-worse/2016/02/17/4c9277be-d59c-1 le5-b195-2e29a4e13425_story.html [http://perma.cc/6D2L-JMRV].

67. Contrary to the President's rhetoric, the draft order cautioned that "[n]o person in the custody of the United States shall at any time be subjected to torture or cruel, inhuman, or degrading treatment or punishment, as proscribed by U.S. law." Draft Executive Order on the Detention and Interrogation of Enemy Combatants, WASH. POST (Jan. 25, 2017), http://apps.washingtonpost.com/g/documents/national/read-the-draftof-the-executive-order-on-cia-black-sites/2288 [http://perma.cc/YH9N-M29U]; Charlie Savage, Trump Poised to Lift Ban on C.I.A. 'Black Site' Prisons, N.Y. TIMES (Jan. 25, 2017), https:/www.nytimes.com/2017/01/25/us/politics/cia-detainee-prisons.html [http://perma.cc/MY34-8EUS].

68. See, e.g., International Covenant on Civil and Political Rights, supra note 27, at art. 7 ("No one shall be subjected to torture or to cruel, inhuman or degrading treatment or punishment."); Convention Against Torture and Other Cruel, Inhuman or Degrading Treatment or Punishment, Dec. 10, 1984, 1465 U.N.T.S. 85; War Crimes Act, 18 U.S.C. $\$ 2441$ (1996) (criminalizing torture); Torture Victim Protection 
vocate General, your Dean, Tom Romig, prominently indicated that he had taken an oath to obey not any particular President, but rather the Constitution and laws of the United States of America. Those laws include a treaty of the United States, the Geneva Conventions, ${ }^{69}$ and a statute, the Uniform Code of Military Justice. ${ }^{70}$ This is where government lawyers play their most critical role: maintaining fidelity to the rule of law to promote longer-term societal stability, even while they accept a new Administration's political direction.

More fundamentally, as Judge Floyd recently noted, "While executive officers can declare the military reasonableness of conduct amounting to torture, it is beyond the power of even the President to declare such conduct lawful." 71 Nor does it matter that Al Qaeda and IS have not signed the Torture Convention or the Geneva Conventions. The United States is bound to foreswear torture not just by reciprocal agreement, but by a treaty-based specification of minimal standards of humane treatment that we must unilaterally obey, whether there is a written agreement or not. ${ }^{72}$ Obviously, enforcing a norm against torture as a universal right serves our national interests, by protecting our own citizens and soldiers when they are captured. But the norm of humane treatment to which we have committed ourselves binds us, as a defining element of our national identity, whether others agree to follow it or not. As Senator John McCain said in responding to Trump's campaign statements: "[T]hese statements must not go unanswered because they mislead the American people about the realities of interrogation, how to gather intelligence, what it takes to defend our security, and, at the most fundamental level, what

Act, 28 U.S.C. $\S 1350$ (1991) (civil remedy); Alien Tort Claims Act, 28 U.S.C. $§ 1350$ (1988) (civil remedy); National Defense Authorization Act for Fiscal Year 2016, Pub. L. No. 114-92, § 1045, 129 Stat. 726, 977 (2015). See also Marty Lederman, The President's NDAA Signing Statement Re: GTMO and Anti-Torture Provisions, JUST SECURITY (Nov. 25, 2015, 9:50), https://www.justsecurity.org/27939/presidents-ndaasigning-statement-re-gtmo-anti-torture-provisions [http://perma.cc/Q4XY-VJ55].

69. Common Article 3 to the four Geneva Conventions, which is considered customary international law, states as a rule of humanity that there should be no violence to life and persons, including no torture or outrages on personal dignity, or sentences without due process. Geneva Convention Relative to the Treatment of Prisoners of War art. 3, Aug. 12, 1949, 6 U.S.T. 3316. Additional Protocol II amplifies these guarantees and outlaws all forms of violence against those persons who are noncombatants. Protocol Additional to the Geneva Conventions of 12 August 1949, and Relating to the Protection of Victims of Non-International Armed Conflicts (Protocol II) art. 4, ๆ 2, June 8, 1977, 1125 U.N.T.S. 609. The Convention Against Torture states that "[n]o exceptional circumstances whatsoever, whether a state of war or threat of war ... may be invoked as a justification for torture." The Convention Against Torture Article 2(2), supra note 68.

70. 10 U.S.C. $\$ 855$ (1956) ("Punishment by flogging, or by branding, marking, or tattooing on the body, or any other cruel or unusual punishment, may not be adjudged by any court-martial or inflicted upon any person subject to this chapter. The use of irons, single or double, except for the purpose of safe custody, is prohibited.").

71. Al Shimari v. CACI Premier Tech., Inc., 840 F.3d 147, 162 (4th Cir. 2016) (Floyd, J., concurring) ("The fact that the President-let alone a significantly inferior executive officer-opines that certain conduct is lawful does not determine the actual lawfulness of that conduct. The determination of specific violations of law is constitutionally committed to the courts, even if that law touches military affairs."); accord Harold Hongju Koh, Can the President Be Torturer in Chief?, 81 IND. L.J. 1145, 1148, 1156 (2006).

72. See Hamdan v. Rumsfeld: Establishing a Constitutional Process, Hearing Before the S. Comm. on the Judiciary, 109th Cong. 51 (2006) (statement of Harold Hongju Koh, Dean, Yale Law School) ("Some have said, well, terrorists have not signed Common Article 3. Well, whales have not signed the Whaling Convention. But it is about how we treat them and how we are obliged to treat them."). 
we are fighting for as a nation."73 Nor should we overlook the scientific fact that at a cellular level, every tactic used in torture for the purpose of extracting information-sleep deprivation, temperature change, waterboarding, food restriction-inhibits, rather than improves, memory, confession, and truthtelling. ${ }^{74}$ So torture simply does not work. It is a profound mistake to pretend that these are "enhanced," as opposed to impaired, interrogation tactics. ${ }^{75}$

In 2013, upon leaving the State Department, I left behind a memo explaining why it is "not legally available to policymakers to claim" that the Convention Against Torture does not apply outside the United States. ${ }^{76}$ In 2015, the Obama Administration made this point explicit in its presentation before the Committee Against Torture in Geneva, stating that the torture ban applies "in all places, at all times, with no exceptions." 77 And the Frameworks Report that President Obama's administration issued during its last days in office stated that "[ $\mathrm{t}]$ orture and cruel, inhuman, or degrading treatment or punishment (CIDTP) are categorically prohibited under domestic and international law, including international human rights law and the law of armed conflict. These prohibitions exist everywhere and at all times."78 In his farewell counterterrorism speech, delivered shortly thereafter, President Obama declared without qualification: "We prohibited torture, everywhere, at all times - and that includes tactics like waterboarding."79 And as President

73. See, e.g., Senator John McCain, Floor Statement by Senator John McCain on Inhumane Interrogation Methods (Feb. 8, 2016), https://www.mecain.senate.gov/public/index.cfm/floorstatements?ID=BEE31 A68-99DE-40F6-844E-27482CBA6240 [http://perma.cc/63M5-CBDK].

74. Shane O'MARA, Why TORTURE DOESN'T WORK: THE NEUROSCIENCE OF INTERROGation (2015); see also Harold Hongju Koh, Pain Versus Gain, Just SECURITY (June 20, 2016, 3:15 AM), https://www.justsecurity.org/ 31544/pain-gain/ [http://perma.cc/HW47-U9A2].

75. See Douglas Johnson et al., The Strategic Costs of Torture: How "Enhanced Interrogation" Hurt America, ForEIGN AFF. (Sept./Oct. 2016), https://www.foreignaffairs.com/articles/united-states/strategiccosts-torture [http://perma.cc/3QXE-BE3B].

76. Harold Hongu Koh, Legal Advisor, U.S. Dep't of State, Memorandum Opinion on the Geographic Scope of the Convention Against Torture and Its Application in Situations of Armed Conflict 5-6 (Jan. 21, 2013) (emphasis added), discussed in Charlie SAVAGE, POWER WARS: INSIDE OBAMA's Post-9/11 PREsIdENCY 535 (2015); See also Marko Milanovic, Harold Koh's Legal Opinions on the US Position on the Extraterritorial Application of Human Rights Treaties, EJL: TALK! (Mar. 7, 2014), http://www.ejiltalk.org/harold-kohs-legal-opinions-on-the-us-position-on-the-extraterritorial-application-ofhuman-rights-treaties [http://perma.cc/AF7Q-R62Y].

77. Karen DeYoung, Obama Administration Endorses Treaty Banning Torture, WASH. Post (Nov. 12, 2014), https://www.washingtonpost.com/world/national-security/obama-administration-endorses-treatybanningtorture/2014/11/12/b6131 e68-6a8c-11 e4-9fb4-a622dae742a2_story.html [http://perma.cc/48MA$\mathrm{X} 2 \mathrm{WH}$ ] (quoting Assistant Secretary of State for Democracy, Human Rights and Labor Tom Malinowski). The former Principal Deputy, then-Acting Legal Adviser Mary McLeod, echoed the same notion, now embedded into U.S. law: that the torture ban applies at all times with no exceptions. Mary E. McLeod, Acting Legal Adviser, U.S. Dep't of State, Acting Legal Adviser McLeod: U.S. Affirms Torture Is Prohibited at All Times in All Places (Nov. 12, 2014), https:/geneva usmission.gov/2014/11/12/acting-legal-adviser-mcleod-us-affirms-torture-is-prohibited-at-all-times-in-all-places [http://perma.cc/G284-NZW2].

78. President Barack Obama, Report on the Legal and Policy Frameworks Guiding the United States' Use of Military Force and Related National Security Operations 32 (2016) [hereinafter FRAMEWORKS REPORT], https://www.justsecurity.org/wpcontent/uploads/20]6/12/framework.Report_Final.pdf [http://perma.cc/SS42-KSGC].

79. President Barack Obama, Remarks by the President on the Administration's Approach to Counterterrorism, THE WHTE HOUSE (Dec. 6, 2016), https://www.whitehouse.gov/the-pressoffice/20]6/12/06/remarks-president-administrations-approach-counterterrorism [http:/perma.cc/Q92S- 
Obama had explained during his campaign, "Torture is how you create enemies, not how you defeat them. ... Torture is how you get bad information, not good intelligence. Torture is how you set back America's standing in the world, not how you strengthen it." 80 So we were done with torture. Why bring it back?

Happily, Donald Trump's penchant for appointing former generals to civilian national security positions seems to have prevented him from doing so. American soldiers are trained to follow the Geneva Conventions and have internalized the norms against torture. Pressed by private letters from dozens of former military leaders, all of President Trump's key senior national security officials - many of them former military - publicly pledged not to follow an order to torture anyone in an array of statements made around the time of their appointments. ${ }^{81}$ Chief of Staff John Kelly, formerly Secretary of Homeland Security; General Mattis, now Secretary of Defense; Mike Pompeo, now Director of the CIA; and Jeff Sessions, Attorney General, all said in their confirmation hearings that they would not follow an order to torture. ${ }^{82}$ As a general, National Security Adviser H.R. McMaster had forbidden his soldiers from using dehumanizing and derogatory language when referring to Iraqis, declaring that "such behavior is inconsistent with the shared values that define a soldier's moral identity." 83

A president cannot implement a command that his subordinates will not obey. So despite Trump's rhetoric, the draft torture order was not issued and is not the law. Once internalized, the anti-torture norm is not so easily ousted.

\section{Climate Change}

The same could be said for the Trump Administration's well-publicized

4B2R].

80. Paul Koring, Choice of Panetta To Head CIA Likely to Raise Hackles in Spy Circles, GLobE \& MAIL (Jan. 10, 2009), https://www.theglobeandmail.com/news/world/choice-of-panetta-to-head-cia-likely-toraise-hackles-in-spy-circles/article20442915 [http://perma.cc/VHR8-CQZJ].

81. Among other public pressure points, a joint letter from 176 generals and admirals helped to put Trump's cabinet nominees on the record against torture. See Letter from 176 Retired Generals and Admirals to President-Elect Trump on the Use of Torture, HUM. RTS. FIRST (Jan. 11, 2017), http://www.humanrightsfirst.org/resource/letter-176-retired-generals-and-admirals-president-elect-trump-usetorture [http://perma.cc/EWB9-GTB5].

82. Kristina Wong, Pentagon: Mattis Still Opposes Torture Despite Trump Comment, THE HILL (Jan. 26, 2017), www.thehill.com/policy/defense/316356-mattis-remains-opposed-to-torture-pentagon-says [http://perma.cc/7SFL-UCGE]; Caroline Kenny, CIA Nominee Says He Would Disregard Trump on Torture, CNN (Jan. 12, 2017, 1:02 PM), www.cnn.com/2017/01/12/politics/trump-cabinet-picks-opposetorture/index.html [http:/perma.cc/P8DK-83ZY].

83. General McMaster went on to say, "[m]aybe to defeat this kind of enemy [IS] you have to be equally brutal. Maybe you have to lower your standards, but I would say that exactly the opposite is the case... . We have to defeat them in a way that's consistent with our values that reflect our society and what's expected of our military, for our Army forces.... We have to fight them applying the principles of just war theory. ... Our soldiers are warriors, but our soldiers are also humanitarians." Adil Ahmad Haque, Can NSA Pick McMaster Bring Ethics to the White House?, NEWSWEEK (Feb. 21, 2017, 1:05 PM), www.newsweek.com/nsa-pick-mcmaster-moral-approach-war-channels-saints-559147 [https://perma.cc/N6EG-M5XK ] (emphasis added). 
statement regarding its "intent to withdraw" from the 2015 Paris Agreement on Climate Change, the landmark treaty establishing national reduction targets for greenhouse gas emissions for all member States. ${ }^{84}$ The Paris Deal was negotiated under the auspices of the United Nations Framework Convention on Climate Change (UNFCCC), a treaty with 196 state parties to which the Senate gave its advice and consent in 1992.

The evolution of the Paris Deal graphically illustrated the engagetranslate-leverage framework applied by the Obama-Clinton approach to international law as smart power. Led by Special Climate Envoy Todd Stern, the Obama Administration did not withdraw, as the George W. Bush Administration previously had from the 1997 Kyoto Protocol, but rather engaged repeatedly with countries around the world to frame the global deal, including at annual Conference of Parties (COP) meetings in Copenhagen, Cancun, Durban and Paris: with the G-20; with the countries of the Major Economies Forum (MEF); with the countries of BASIC (Brazil, South Africa, India, and China), especially China; and in scores of other bilateral meetings with countries large and small. Instead of treating climate change as an area without law, the United States translated from norms inchoate in the rigid, legally binding, top-down Kyoto architecture, which specified internationally negotiated emissions targets that applied only to developed countries, to a much more informal, politically binding, bottom-up Copenhagen blueprint infused with stronger norms and with greater symmetry between the duties of developed and developing nations. This intense diplomacy allowed the Obama Administration to leverage these principles into an innovative architectural design that required a "double trigger" acceptance by at least fifty-five parties of the UNFCCC that accounted for at least $55 \%$ of greenhouse gas emissions. That led to the Paris Agreement, which entered into force with more than 150 parties on November 4, 2016, just four days before the election of Donald Trump. Yet, after the initial euphoria surrounding the treaty, on June 1, 2017, President Trump announced his intent for the United States to "withdraw" from the Paris Agreement: an action again driven by a philosophy of "disengage-black hole-hard power."

But President Trump's rhetoric launched little meaningful legal actionfor the simple reason that his announcement did not legally disengage. International law makes clear that U.S. presidents cannot simply delete prior signatures from treaties. President George W. Bush demonstrated the futility of announcing a withdrawal under terms not designated by an international

84. This section and the next draw upon Harold Hongju Koh, Triptych's End: A Better Framework to Evaluate 21st Century International Lawmaking, 126 YALE L.J. F. 337 (Jan. 17, 2017), http://www.yalelawjournal.org/pdf/KohMacroedFinal_b7ccaqrm.pdf [http://perma.cc/QF2K-8XYM], and Harold Hongju Koh et al., Trump's So-Called Withdrawal from Paris: Far from Over, JUST SECURITY (June 2, 2017), https://www.justsecurity.org/41612/trumps-so-called-withdrawal-paris [https://perma.cc/WYM2JEU7]. 
agreement when he tried to "unsign" the Rome Statute (which established the International Criminal Court). The "unsigning" letter his administration sent to the U.N. had uncertain effect under customary international law, leaving the U.S. signature on the Rome Statute, which allowed the United States to reengage with the Rome Statute parties during the eight years of the Obama Administration. ${ }^{85}$ The Paris Agreement only recognizes withdrawal under the terms specified in the Agreement's text, which plainly declares that a party cannot give notice of withdrawal to the U.N. Secretary General until "three years from the date on which this Agreement has entered into force." 86 Since the Paris Agreement entered into force on November 4, 2016, the earliest date that the U.S. could even give such legal notice would be November 4, 2019. That notification would then take another year to take legal effect, meaning that Trump cannot legally withdraw the U.S. from the Agreement until November 4, 2020, the day after the next U.S. presidential election.

Until then, Trump's withdrawal announcement has no more legal meaning than one of his tweets. ${ }^{87}$ The United States has not "virtually" or "preemptively withdrawn" or otherwise formally disengaged in any way as a party from the Paris Agreement. At this writing, the United Nations Treaty Depositary page on the Paris Agreement still lists the United States as a party. ${ }^{88}$ While the State Department website indicates that it has notified the U.N. Depositary of its "intent to withdraw," a "media note" makes clear that all the United States has done is communicate "the U.S. intent to withdraw from the Paris Agreement as soon as it is eligible to do so, consistent with the terms of the Agreement." 89 So in the words of a quickly formed coalition of Paris supporters, "We Are Still In." Unlike Trump's, America's commitment to fighting climate change is irreversible. ${ }^{90}$ Under similar circumstances, the United States was in arrears of its United Nations dues for many years, but never quit its membership and eventually came back into compliance in recent years.

For now, Trump's withdrawal "announcement" has no more legal force

85. Harold Hongiu Koh, International Criminal Justice 5.0, 38 YALE J. INT'L L. 525 (2013), http://digitalcommons.law.yale.edu/cgi/viewcontent.cgi?article $=1436 \&$ context=yjil [http://perma.cc/YJ3L$3 \mathrm{~V} 4 \mathrm{X}]$. If anything, the claimed "unsigning"- - announced in a letter sent by vocal U.N. opponent John Bolton-only focused the attention of other parties on the U.S.'s continuing obligations as a treaty signatory not to defeat the object and purpose of the Rome Statute under Article 18 of the Vienna Convention on the Law of Treaties.

86. Paris Agreement of the United Nations Framework Convention on Climate Change [hereinafter Paris Agreement] art. 28.1, Apr. 22, 2016, T.I.A.S. No. 16-1104 (entered into force Nov. 4, 2016).

87. President Donald Trump, Statement by President Trump on the Paris Climate Accord (June 1, 2017), https://www.whitehouse.gov/the-press-office/2017/06/01/statement-president-trump-paris-climateaccord [https://perma.cc/3H7X-6SFG].

88. Paris Agreement, supra note 86.

89. See Press Release, Communication Regarding Intent to Withdraw From Paris Agreement, U.S. DEP'T OF STATE, (Aug. 4, 2017), https:/www.state.gov/r/pa/prs/ps/2017/08/273050.htm [https://perma.cc/V8GP-XD6U].

90. See WEARESTILLIN, https:/www.wearestillin.com/ [https://perma.cc/M47V-BWRC] 
than an employee's empty threat to leave his job in three years' time. As with the North American Free Trade Agreement (NAFTA), Trump initially claimed that he plans to "renegotiate" a better agreement, but the other 190 state parties have no incentive to renegotiate a weaker agreement with a flailing American administration that may already have been voted out of office when the time comes to complete its withdrawal. In August 2017, Ambassador Haley informed the U.N. Secretary-General of the U.S.'s intent "to exercise its right to withdraw from the Agreement [u]nless the United States identifies suitable terms for reengagement," whatever that might mean. ${ }^{91}$ In its August statement, ${ }^{92}$ the State Department further announced that the United States would continue to participate in the UNFCCC Conference of Party (COP) meetings, where, as a prospectively exiting party, the United States delegation's influence will surely be greatly diminished. So if the United States continues to participate in the Paris process and remains a state party for the balance of Trump's first term, it has not meaningfully withdrawn; it has only reduced its own influence by identifying itself as a lame duck. While President Trump claimed that his withdrawal announcement "represents a reassertion of America's sovereignty," 93 in reality, he unilaterally surrendered our influence over the agreement to China and the other BASIC countries, which have reaffirmed their Paris commitments and will push the United States to keep its own. ${ }^{94}$

While Trump has committed an egregious self-inflicted wound by preemptively announcing his intent to withdraw, for the next three years, there is little reason to treat that withdrawal announcement as either definitive or final. Since the announcement, the Administration has sent confusing messages to U.S. allies as to whether it will actually follow through when the time comes. ${ }^{95}$ Meanwhile, bureaucratic stickiness and external litigation have slowed the pace of domestic dismantling of our Paris commitments. Many elements of the Paris Agreement compliance plan have already been internalized into the federal administrative agenda and are not so easily ousted. The Administration's March 2017 Climate Executive Order calls for reversing course on the Clean Power Plan (CPP), an agency rule that pushes for inter-

91. Nikki Haley, U.S. Ambassador to the U.N., Diplomatic Note to the U.N. Secretary-General (Aug. 4, 2017).

92. Press Release, supra note 89.

93. Trump, supra note 87.

94. Geoffrey Smith, Germany and China Position Themselves as World Climate Leaders, FORTUNE (June 1, 2017), www.fortune.com/2017/06/01/paris-agreement-germany-china-trump

[https://perma.cc/V2CC-5EJP]. For example, the Indian Supreme Court has recently backed tougher emissions standards, which may improve its own international bargaining leverage in the years ahead. Amy Kazmin, Indian Court Backs Drive for Tough Auto Emissions Standards, Fin. TIMES (Mar. 29, 2017), https:/www.ft.com/content/4lb4f4bc-1483-1 le7-80f4-13e067d5072c [https://perma.cc/8FA2-77BT].

95. See Emre Peker, Trump Administration Seeks to Avoid Withdrawal from Paris Climate Accord, WALL ST. J. (Sept. 16, 2017, 5:16 PM), https://www.wsj.com/articles/trump-administration-wont-withdrawfrom-paris-climate-deal-1505593922 [https://perma.cc/4VPP-K83J] (noting statement by Trump official at diplomatic meeting that the U.S. would stay in under "the right conditions"). 
state cap-and-trade and for states to build fewer coal-burning plants while creating greater capacity for renewable energy. The EPA's authority to implement the Clean Power Plan - the main federal administrative program to implement the U.S.'s Paris commitments - was stayed 5-4 by the Supreme Court in 2016 (with the late Justice Scalia in the majority). ${ }^{96}$ At this writing, the D.C. Circuit en banc is deciding whether the EPA has authority to implement the CPP. ${ }^{97}$ Meanwhile, the court has pointedly reminded the government that the EPA has an "affirmative statutory obligation to regulate greenhouse gases."98 The EPA is apparently planning to issue a proposal to undo the CPP, along with a separate advance notice of its intent to consider a replacement. This keeps virtually all options on the table-including ultimately keeping the CPP in place. ${ }^{99}$ An overt effort by the Trump Administration to discard the plan would undoubtedly trigger new fights about notice-andcomment rulemaking before the D.C. Circuit, who will pass on the legality of any new proposed agency action. In such litigation, environmental groups could well claim that the President has failed to faithfully execute continuing U.S. international legal obligations under the Paris Accords, with any appeals to Chevron deference compromised by competing agency interpretations of the same Clean Air Act provisions.

Should the Trump Administration attempt other changes, domestic litigation seems inevitable. Undoing EPA rules that mandate fuel and energy efficiency standards would likely require a new regulatory process that will be subject to notice-and-comment rulemaking and stakeholder inputs. ${ }^{100}$ Even if Trump's EPA tries to review the fuel economy standards, they are locked in until 2021, at which point a new President may take office. ${ }^{101}$ When the Trump EPA tried to stay enforcement of the Methane Rule and argued that its

96. West Virginia v. E.P.A., 136 S. Ct. 1000 (2016).

97. West Virginia v. E.P.A., No. 15-1363 (D.C. Cir. Sept. 27, 2016). The D.C. Circuit recently decided to extend its holding of the case in abeyance for another sixty days, until October 7, 2017, and to mandate that the EPA provide status reports every thirty days while the agency considers its path forward. Order, West Virginia v. E.P.A., No. 15-1363 (Aug. 8, 2017).

98. Order, W. Virginia v. E.P.A., No. $15-1363$ (Millet, J. \& Tatel, J., concurring). Judges Tatel and Millett, concurring in the order extending the abeyance, noted that this statutory obligation is left indefinitely unfulfilled given the Supreme Court's stay in combination with the D.C. Circuit's order-but that the issue is for the Supreme Court, not the Circuit, to decide. See John H. Cushman, Jr., Obama's Clean Power Plan: What to Know About the Newest Legal Showdown, Inside Climate News (May 17, 2017), https://insideclimatenews.org/news/16052017/clean-power-plan-epa-lawsuit-trump-obama-climate-change [https://perma.cc/2JK2-L4RH].

99. Emily Holden, Trump May Replace Obama's Big Climate Rule-Not Just Repeal It, POLITICO (Sept. 14, 2017, 7:05 PM), http://www.politico.com/story/2017/09/14/trump-administration-may-replacekey-obama-climate-rule-242747 [https://perma.cc/2KY4-WRAT].

100. See Nathan Hultman, What a Trump Presidency Means for U.S. and Global Climate Policy, BRoOKINGS (Nov. 9, 2016), https:/www.brookings.edu/blog/planetpolicy/2016/11/09/what-a-trumppresidency-means-for-u-s-and-global-climate-policy [https://perma.cc/553E-AJJV] ("Trump can slow down new initiatives but would have a hard time unwinding all of the processes that have been put in place over the last nearly decade of intense work by the current administration.").

101. Coral Davenport \& Bill Vlasic, Trump Using Detroit as Stage for Loosening Obama's Fuel Economy Rules, N.Y. TIMES (Mar. 15, 2017), https://www.nytimes.com/2017/03/15/us/politics/trump-obama-fueleconomy-standards.html [https://perma.cc/FM92-H3WF]. 
decision to do so was immune from judicial review, the court found the action "arbitrary and capricious" and considered it an effective revocation that fell outside the agency's authority under the Clean Air Act. ${ }^{102}$ The court went on to rule that the EPA would have to initiate full rulemaking procedures to undo the regulation and that until then the agency must enforce the Methane Rule. ${ }^{103}$ Although litigation over regulation of hydrofluorocarbons continues, a new agreement was recently concluded in Montreal. ${ }^{104}$ While the federal government may seek to revoke California's waiver under the Clean Air Act, California will surely fight to keep it. ${ }^{105}$

If, in November 2019, the Administration should unilaterally give notice of its intent to withdraw from Paris, new litigation would almost certainly ensue, arguing that the President lacks constitutional power to withdraw from the Paris Agreement without congressional participation. ${ }^{106}$ Admittedly, the precedent most on point is the Supreme Court's summary disposition nearly four decades ago in Goldwater v. Carter ${ }^{107}$ Goldwater concerned a Senator's challenge to the President's decision unilaterally to terminate a bilateral mutual defense treaty with Taiwan in accordance with its terms, which was ultimately dismissed on political question grounds. But in Goldwater, the political branches had not yet reached "constitutional impasse," and only one Justice voted on the merits to uphold the President's treaty termination power, based on the peculiar fact that the case - unlike climate change-involved recognition of foreign governments, an issue over which the President plainly exercises plenary constitutional power. ${ }^{108}$ In the protracted Zivotofsky litiga-

102. Lisa Friedman, Court Blocks E.P.A. Effort to Suspend Obama-Era Methane Rule, N.Y. TIMEs (July 3 , 2017), https:/www.nytimes.com/2017/07/03/climate/court-blocks-epa-effort-to-suspend-obama-eramethane-rule.html [http://perma.cc/2JZY-VMHH].

103. Rene Marsh, EPA Ordered to Enforce Obama-Era Methane Pollution Rule, CNN (Aug. 1, 2017, 12:55 AM), http://www.cnn.com/2017/07/31/politics/dc-circuit-epa-methane-rule/index.html [https://perma.cc/W6SS-P33T].

104. The 2015 rule was just struck down by the D.C. Circuit. Ari Natter, Court Tosses an Obama-Era Climate Rule that Trump Had Defended, BloOMBerg (Aug. 8, 2017, 11:20 AM), https://www.bloomberg.com/news/articles/2017-08-08/u-s-court-tosses-one-obama-era-climate-rule-trumphad-defended [http://perma.cc/QP7J-C4BB]; Coral Davenport, Nations, Fighting Powerful Refrigerant That Warms Planet, Reach Landmark Deal, N.Y. TIMES (Oct. 15, 2016), https://www.nytimes.com/2016/10/15/world/africa/kigali-deal-hfc-air-conditioners.html [https://perma.cc/T38A-Q7SZ].

105. Robinson Meyer, The Coming Clean-Air War Between Trump and Califormia, ATLANTIC (Mar. 6, 2017), https://www.theatlantic.com/science/archive/2017/03/trump-california-clean-air-act-waiver-climatechange/518649 [https://perma.cc/VD7S-GF29].

106. The recent British Supreme Court decision in the Brexit litigation held that the U.K. government may not use its executive prerogative powers, but rather must seek parliamentary approval, to trigger Article 50 , the withdrawal provision of the Treaty of the European Union, particularly if fundamental rights are affected. R (Miller) v. Secretary of State for Exiting the European Union [2017] UKSC 5, [2017] 2 W. L. R. 583.

107. 444 U.S. 996 (1979) (per curiam) (dismissing on political question grounds); id. at 1006 (Brennan, J., dissenting) (citing the President's plenary textual recognition power as a basis for affirmance on the merits); see also Kucinich v. Bush, 236 F. Supp. 2d 1 (D.D.C. 2002) (finding the question of executive authority to withdraw from the Anti-Ballistic Missile Treaty to be a nonjusticiable political question).

108. See Carter, 444 U.S. at 996 (Powell, J., concurring) ("The Judicial Branch should not decide issues affecting the allocation of power between the President and Congress until the political branches reach a constitutional impasse."); id. at 1006 (Brennan, J., dissenting) (citing the President's plenary textual recognition 
tion, the Court recently declined a similar political-question challenge to an assertion of the President's recognition power. ${ }^{109}$ Yet even if a litigation challenge ultimately proved unsuccessful, the litigation could still last more than a year, thereby pushing the national decision of whether to complete withdrawal past Trump's presidency.

Those resisting Trump's initiatives are not simply playing rope-a-dope. Widespread support for climate change solutions continues to grow among other transnational actors. Through the Under2 MOU coalition, states, provinces, regions, and cities around the world have pledged the common goal of reducing greenhouse gas emissions to $80-95 \%$ below 1990 levels by $2050 .^{110}$ Already, the Governors of California, New York, and Washington have formed the United States Climate Alliance, a coalition that will bring together U.S. states to uphold the Paris Agreement and take further climate action. ${ }^{111}$ Similarly, through the Compact of Mayors, 600 global cities have pledged to reduce greenhouse gas emissions by nearly one billion tons annually by 2030 . California alone could bring us $5 \%$ of the way to our global pledge, which is to cut our emissions by $26 \%-28 \%$ below 2005 levels by 2025.112 And emissions trading among subnational entities seems plainly possible under Paris Article 4.2.113

Although President Trump claims the Paris Agreement would provide other countries with "an economic edge" over the United States, ${ }^{114}$ business leaders instead believe that future economic prosperity is best advanced by remaining in and supporting the Paris Agreement. Coal jobs will continue to be scarce. Default patterns have shifted toward clean energy and cannot be undone overnight. New power plants are much more likely to use cheap gas or renewables. The Breakthrough Energy Coalition, pioneered by Bill Gates, will invest $\$ 1$ billion in companies that provide affordable clean energy. ${ }^{115}$

power as a basis for affirmance on the merits)

109. Zivotofsky ex rel. Zivotofsky v. Clinton, $132 \mathrm{~S}$. Ct. 1421, 1430 (2012) (reversing the lower court's political question ruling on the ground that the "[r]esolution of [plaintiff"s] claim demands careful examination of the textual, structural, and historical evidence put forward by the parties regarding the nature of the [law in question] and of the [constitutional] powers [in dispute]" and asserting that "[t]he political question doctrine poses no bar to judicial review of this case").

110. Background on the Under2, UNDER2 ${ }^{\circ}$, http://under2mou.org/background [https://perma.cc/U79G-MCV6].

111. Eric Wolff, Washington, California, New York Band Together to Form Climate Alliance, PoLITICO (June 1, 2017, 6:31 PM), http://www.politico.com/story/2017/06/01/climate-alliance-washington-californianew-york-239038 [https:/perma.cc/WF7K-35CL].

112. Press Release, The Global Covenant of Mayors for Climate \& Energy Announces Its Global Impact, Glob. COVEnANT OF MAYORS FOR Climate \& ENERGY (Nov. 13, 2016), http://www.globalcovenantofmayors.org/press/global-covenant-mayors-climate-energy-announcescollective-impact-cities-move-paris-agreement-commitment-action [https:/perma.cc/6FZG-6JBF].

113. Paris Agreement, supra note 86, at art. 4.2; See also INTERNATIONAL EMISSIONS TRADING Association, GHG Market Sentiment Survey 201610 (11 th ed. 2016).

114. Trump, supra note 87.

115. BREAKTHROUGH ENERGY, http:/www.b-t.energy [https://perma.cc/XC53-JKBU]; Kerry A. Dolan, Bill Gates Launches \$1 Billion Breakthrough Energy Investment Fund, ForBES (Dec. 12, 2016, 1:31 PM), https://www.forbes.com/sites/kerryadolan/2016/12/12/bill-gates-launches-1-billion-breakthrough-energyinvestment-fund [http://perma.cc/E5CB-LF7F]. 
Through the "We Mean Business" Coalition, 471 companies with over $\$ 8$ trillion in market capitalization have undertaken more than 1000 climate action commitments. ${ }^{116}$ For this same reason, hundreds of major companies and investors--including DuPont, eBay, Nike, Unilever, Levi Strauss \& Co., Hilton, Adobe, Apple, Facebook, Google, and Hewlett Packard--have publicly urged President Trump to remain in the Paris Agreement. ${ }^{117}$ Even oil and gas companies-including Shell and Exxon Mobil-have endorsed remaining in the Agreement. ${ }^{118}$

Since Trump's announcement, many U.S. climate stakeholders other than the federal government-such as states and localities ${ }^{119}$ and private clean energy entrepreneurs-have intensified their efforts toward meeting the Paris targets. ${ }^{120}$ These alternative stakeholders will almost surely generate an alternative plan of litigation and emissions reduction designed to keep U.S. emissions within striking distance of the promised U.S. Nationally Determined Contribution. As the Trump Administration waffles, the global community can keep doing what it is doing. It can disregard as legally meaningless the Trump Administration's prospective "withdrawal" from the Paris Agreement, and instead look to these subnational and business leaders' efforts to meet the greenhouse gas emissions reductions pledged by the U.S. under the Paris Agreement. ${ }^{121}$ Even if the U.S. does fall into arrears on emissions reductions or green climate fund contributions, as it has done in the past with respect to its U.N. dues, these other domestic and international stakeholders can exert pressure to force this Administration and the next to make up the difference in a more climate-friendly administration.

In short, Trump's claimed withdrawal from the Paris Agreement marks just the beginning of the transnational legal process story. The outside strategy of "interaction-interpretation-internalization" is playing out even as we watch. And inside the government, the Trump plan to undo Paris is encountering bureaucratic obstacles. While the "disengage-black hole-hard power" faction won the day in June 2017, since then, the "engage-translate-leverage" approach has made a comeback, forcing continued engagement at the COPs to

116. Ambitious Corporate Action Driving Delivery of Paris Goals, WE MEAN BUS. COALITION (Nov. 9, 2016), https://www.wemeanbusinesscoalition.org/content/ambitious-corporate-action-driving-delivery-parisgoals [http://perma.cc/A8M4-S2YQ].

117. Merrit Kennedy, Hundreds of U.S. Businesses Urge Trump to Uphold Paris Climate Deal, NPR (Nov. 17, 2016, 11:54 AM), http://www.npr.org/sections/thetwo-way/2016/11/17/502425711/hundreds-of-us-businesses-urge-trump-to-uphold-paris-climate-deal [https://perma.cc/8X78-WW5W]; Low-CARBON USA, Business Backs Low-Carbon USA, http://lowcarbonusa.org/business [http://perma.cc/RX3Z-PXKL].

118. Samantha Raphelson, Energy Companies Urge Trump to Remain in Paris Climate Agreement, NPR (May 18, 2017, 6:32 PM), www.npr.org/2017/05/18/528998592/energy-companies-urge-trump-to-remain-inparis-climate-agreement [https://perma.cc/FJ36-AZWJ].

119. See Hultman, supra note 100.

120. Id.

121. Hiroko Tabuchi \& Henry Fountain, Bucking Trump, These Cities, States and Companies Commit to Paris Accord, N.Y. TIMES (June 1, 2017), https://www.nytimes.com/2017/06/01/climate/american-citiesclimate-standards.html [https://perma.cc/5C79-WYFU]. 
try to get better conditions at the margins of the Paris Agreement. Trump's effort to withdraw has been stymied not just by career bureaucrats, but also by his own political appointees - such as Tillerson, Energy Secretary Rick Perry, National Security Adviser H.R. McMaster, and economic adviser Gary Cohn. All of them favor "engaging" (i.e., keeping a seat at the table) and "translating" (i.e., reading ambiguities in the treaty to permit lower U.S. environmental performance) over overt withdrawal, which they correctly see as leading to lost leverage in the COP process. And even if the Administration ends up trying to withdraw in accordance with the Agreement's terms, it will be treating the Paris Agreement as bona fide international law that the United States has already internalized to a surprising degree.

The main message is that the Trump Administration does not own our climate policy. We all do. And if the federal government does not live up to its Paris commitments, many other players can fill the gap. Even as Trump says, "we're leaving," the rest of us can say (as the song goes) "I'm telling you, we're not going." 122 There are many resisters, and many ways to resist.

Most important, the Paris Agreement was a bold global bet that developed and developing nations would all cooperate to reduce greenhouse gas emissions through incentives to develop clean energy. The environmental community and the global commitment to clean energy are far bigger than Donald Trump. His administration remains visibly divided on this issue and he has personally demonstrated little meaningful commitment or capacity to follow through on any of his public statements. As Trump's policies and credibility fray on many fronts, time will tell whether his so-called Paris "withdrawal" will be just another one of them. With concerted effort, aggressive innovation, and a bit of luck, in Humphrey Bogart's words, "we'll always have Paris."123

\section{Iran}

Much the same could be said about the so-called Iran Nuclear Deal, which candidate Trump threatened to "rip up."124 The July 14, 2015 comprehensive nuclear deal between Iran and the P5+1 (known as the Joint Comprehensive Plan of Action, or JCPOA) envisions actions by Iran, the United States, the International Atomic Energy Agency (IAEA), and the allies known as the P5+1 (the U.S., the U.K., France, Germany, China, and Russia, plus the European Union). ${ }^{125}$ After extended negotiation, Iran agreed to specified lim-

122. Jennifer Holliday, And I Am Telling You I'M Not GoING (Geffen Records 1982),

123. CASABLANCA (Warner Bros. 1942).

124. Tim Daiss, Trump Pledges To Rip Up Iran Deal; Israelis Say Not So Fast, ForBes (Nov. 22, 2016, 1:50 AM), http://www.forbes.com/sites/timdaiss/2016/11/22/trumps-iran-deal-rhetoric-israelis-say-not-sofast [https://perma.cc/Q422-SDWC].

125. For the full text of the JCPOA, which consists of the agreement itself and five technical annexes, see Joint Comprehensive Plan of Action, U.S. Dep't of State, http://www.state.gov/e/eb/tfs/spi/iran/jcpoa 
its on its nuclear development program in exchange for the P5+1's undertaking to lift domestic and international sanctions that had been imposed through the United Nations.

Once again, the Iran Nuclear Deal illustrated the Obama-Clinton "engage-translate-leverage" "smart power" framework in action. The Obama Administration engaged with Iran, the P4 plus the E.U., the United Nations, and the IAEA. It translated Iran's desire to maintain a civil nuclear program into a deal that verifiably cut off Iran's pathways to a nuclear weapon while allowing Iran to engage in certain exclusively peaceful nuclear activities - all without endorsing a legal right to enrich-and gaining unprecedented monitoring access for the IAEA. The Obama team then leveraged that core norm first with the strengthening of sanctions in June 2010, ${ }^{126}$ followed by the gradual lifting of national and multilateral sanctions and the increasing of international inspection to achieve an outcome that would likely have been unattainable through military force. As concluded, the Joint Comprehensive Plan of Action reduced Iran's stockpiles of enriched uranium by $98 \%$, forcing shipment of 25,000 pounds out of the country. The Plan increased the time that it would take Iran to acquire enough material for one bomb from 2-3 months to at least 1 year, reduced the number of Iran's installed centrifuges by two-thirds, prevented Iran from producing weapons-grade plutonium, and verified the terms of the deal with robust IAEA monitoring and inspections.

At this writing, the JCPOA seems to be fragile, but functioning. ${ }^{127}$ As with the Paris Deal, the created regime of cooperation has become the focal point for all interested stakeholders' expectations. Under domestic and international law, the JCPOA is a politically, not legally, binding arrangement. It is implemented on the U.S. side largely through executive branch waivers of nuclear-related sanctions in exchange for Iran dismantling its nuclear infrastructure under the watch of the IAEA. The IAEA, which, as a creature of international law, has a vested interest in following international law, continues to report that Iran is in compliance with the JCPOA. In January 2016, Iran dismantled much of its nuclear program, in accordance with the agreement reached by the P5+1. Under the terms of the accord, the U.S. and the E.U. removed their nuclear-related domestic sanctions, and the U.N. Security Council lifted similar sanctions under Resolution 2231, which terminated and replaced past resolutions. Meanwhile, Iran has carefully avoided acting to decrease its "breakout time." This suggests that Iran will not violate the deal in

[http://perma.cc/875H-XPE9]. The Annexes include: Annex I, Nuclear Related Commitments; Annex 2, Sanctions Related Commitments; Annex III, Civil Nuclear Cooperation; Annex IV, Joint Commission; and Annex V, Implementation Plan.

126. S.C. Res. 1929 (June 9, 2010).

127. See Alex Ward, Trump Says Iran Is Violating the Nuclear Deal. It Isn't., Vox (Aug. 7, 2017, 9:00 AM), https://www.vox.com/2017/8/7/16089848/trump-iran-deal-nuclear-spirit-rip-up [http://perma.cc/5V4H6ACE]. 
a significant way, even while it tests the accord's limits, particularly with respect to technical provisions - perhaps to create space to negotiate with the $\mathrm{P} 5+1$ on further sanctions relief. The key political commitments in the deal have already been fulfilled, and they are in any event multilateral, sequential, and enforced by existing domestic sanction authorities.

Should the Iranians continue to keep their part of the bargain, the Trump Administration would be hard-pressed to replace with nothing a multilateral deal that seems to be working. The other partners to the deal-the Europeans, the Russians, and the Chinese-will not default on their political obligations just because Donald Trump wants to tear the deal up. ${ }^{128}$ Nor will they return unilaterally to reimposing sanctions on Iran. Meanwhile, the network of trade deals being struck between their businesses and Iran's will likely continue to multiply. Under this umbrella of inter-governmental cooperation, Iran's economy seems to be recovering. Iran has made deals to expand its oil fields, build cars, buy anti-aircraft systems from Russia, and purchase dozens of aircraft from European and American companies. Consistent with the deal's sanctions relief, the U.S. released its hold on tens of billions of dollars in frozen Iranian oil revenues. ${ }^{129}$ Gradual re-enmeshment of the foreign and Iranian banking sectors continues. ${ }^{130}$ And some Israelis have become strikingly hesitant to encourage the President to carry through on his threats to kill the deal, which has won over advocates within Israel as a peaceful alternative that has "blocked Iran's path to a nuclear weapon, and prevented the emergence of an arms race in the Middle East." 131

At this writing, President Trump has attacked the Iran Nuclear Deal before the United Nations and, after twice certifying Iran's compliance with the deal, announced that he would not certify it a third time because Iran had "committed multiple violations of the agreement [and] ... [was] not living up

128. See Joshua Keating, What Happens If Trump Blows Up the Iran Deal?, SLATE (Nov. 17, 2016, 3:38 PM), http://www.slate.com/blogs/the_slatest $/ 2016 / 11 / 17 /$ what_happens_if_trump_blows_up_the_iran_deal.h $\mathrm{tml}$ [http://perma.cc/4GZV-33QC] (noting that "EU governments . . . recently reaffirmed their commitment to continue with the deal").

129. Oren Dorell, Could Trump Trash the Iran Deal? Yes, but It's Complicated, USA TODAY (Nov. 10, 2016), http://www.usatoday.com/story/news/world/2016/11/10/could-trump-trash-iran-deal-yes-but-scomplicated/ 93568040 [http://perma.cc/RX4C-3WVM].

130. See Dan Joyner, The Trump Presidency and the Iran Nuclear Deal: Initial Thoughts, EJIL: TALK! (Nov. 17, 2016), http://www.ejiltalk.org/the-trump-presidency-and-the-iran-nuclear-deal-initial-thoughts [http://perma.cc/HC2W-WQAK] ("If the U.S. were to re-impose or even strengthen secondary banking sanctions on foreign banks, it's hard to say if this would have any effect on the pace of re-engagement with Iran by European and Asian businesses, mostly because those businesses have already had to find ways to work around unclear U.S. banking sanctions ....").

131. Daiss, supra note 124 (quoting Shemuel Meir, former analyst for the Israeli Defense Forces and researcher at Tel Aviv University); see also Carmi Gillon, The Iran Nuclear Deal Has Been a Blessing for Israel, FOREIGN POL'Y (July 13, 2017), http://foreignpolicy.com/2017/07/13/the-iran-nuclear-deal-has-beena-blessing-for-israel-jcpoa [http:/perma.cc/TFT5-ECAT] (noting that "while a majority of my colleagues in the Israeli military and intelligence communities supported the deal once it was reached, many of those who had major reservations now acknowledge that it has had a positive impact on Israel's security and must be fully maintained by the United States and other signatory nations"). 
to the spirit of the deal."132 However, Trump has not gone so far as to withdraw from or renegotiate the agreement, instead pushing to Congress the decision whether or not to reimpose sanctions. As such, the United States currently remains within the bounds of the JCPOA, though the chance that it might collapse due to U.S. noncompliance or Iranian retaliation has increased. ${ }^{133}$ Meanwhile, the IAEA has now certified for the eighth straight time that Iran remains in compliance with the deal. ${ }^{134}$

In theory, Trump could change course and decline to waive U.S. statutory sanctions in response to future Iranian actions, but Iran could nevertheless choose to fulfill its JCPOA nuclear commitments anyway, to benefit from the continued lifting of U.N. and E.U. sanctions. The Trump Administration could also unilaterally trigger the "snapback" mechanism of Resolution 2231, which allows any P-5 member to initiate reimposition of the comprehensive U.N. sanctions by claiming a violation, without a vote by the U.N. Security Council. But other stakeholders may not agree that such a violation has occurred. Even if the U.N. sanctions that were in place before the deal were legally reimposed, it seems unlikely that the other Security Council members, particularly China and Russia, would enforce them. However, were the JCPOA to fall apart, the access of the IAEA to conduct inspections would also disappear, and that agency would no longer be in a position to verify the exclusively peaceful nature of Iran's program. Worst of all, Iranian officials, claiming reciprocal breach by the United States, could claim just cause for restarting their nuclear program and build a bomb. As with repealing Obamacare, a Republican Congress would be skeptical of imposing new sanctions without a better deal in place. The new Administration would simply have created another "lose-lose" situation, blowing up a preexisting deal without creating a new one, losing in the process its allies, its leverage, and its guaran-

132. President Donald Trump, Remarks by President Trump on Iran Strategy, THE WHITE HouSE (Oct 13, 2017), https://www.whitehouse.gov/the-press-office/2017/10/13/remarks-president-trump-iran-strategy [http://perma.cc/SPA3-H76E] (citing Iran's violations as "exceed[ing] the limit of 130 metric tons of heavy water, ... fail[ing] to meet [U.S.] expectations in its operation of advanced centrifuges, ... [and] intimidat[ing] international inspectors"; President Trump also denounced Iran for violating "the spirit of the deal"); Julian Borger, Trump's Debut at the UN: Threats, Taunts-and Gasps of Alarm from the Diplomats, GUARDIAN (Sept. 23, 2017, 4:00 PM), https://www.theguardian.com/us-news/2017/sep/23/donald-trumpunited-nations-general-assembly [http://perma.cc/DP5K-EGGA]; Scott Neuman, State Department Certifies Iran's Compliance with Nuclear Deal, NPR (July 17, 2017), http:/www.npr.org/sections/the-twoway/2017/07/17/537793465/state-department-certifies-irans-compliance-with-nuclear-deal

[http://perma.cc/AX57-5QWM]; Oren Dorell, Tillerson: Iran Complying with Nuclear Deal but Causing Trouble Elsewhere, USA TODAY (Apr. 19, 2017, 3:21 PM),

https://www.usatoday.com/story/news/world/2017/04/19/tillerson-iran-complying-nuclear-deal/100660076 [http://perma.cc/C5EG-MJR3].

133. Mark Landler \& David E. Sanger, Trump Disavows Nuclear Deal and Denounces Iranian Leadership, N.Y. TIMEs (Oct. 13, 2017), https:/www.nytimes.com/2017/10/13/us/politics/trump-iran-nucleardeal.html [http://perma.cc/4TFZ-J77C]; Jana Winter et al., Trump Assigns White House Team to Target Iran Nuclear Deal, Sidelining State Department, FOREIGN POL'Y (July 21, 2017), http://www.foreignpolicy.com/2017/07/21/trump-assigns-white-house-team-to-target-iran-nuclear-dealsidelining-state-department [http://perma.cc/AA7E-Z5JJ].

134. Colin Kahl, The Myth of a 'Better' Iran Deal, FOREIGN POL'Y (Sept. 26, 2017), http://foreignpolicy.com/2017/09/26/the-myth-of-a-better-iran-deal [http://perma.cc/DZ76-6YP6]. 
teed visibility into the Iranian nuclear program.

For all of these reasons, "Trump's advisers are putting out signals that rather than simply scrapping the Joint Comprehensive Plan of Action, ... his administration will try to renegotiate it to get more favorable terms." 135 But that cannot happen if other JCPOA participants refuse to renegotiate. Even if talks were now reopened, the new Administration could hardly get a better deal because the U.S. could not invoke as leverage the crushing multilateral sanctions that brought Iran to the table in the first place. All the key Republicans (e.g., House Speaker Paul Ryan and Senate Foreign Relations Committee Chair Bob Corker) see ripping up the deal as not worth the downsides, and many in the Trump Administration are quietly admitting that the deal will not be withdrawn.

Of course, as with the Paris Agreement, under the Trump Administration, the JCPOA could die a "death by a thousand cuts." For example, the U.S. government could underperform its commitments under the JCPOA by having the Treasury actively discourage third-country investment and at the same time overplay its interpretation of Iranian commitments, with a hair trigger for sanctions in response to claimed Iranian breaches. Because Trump has declined to certify Iranian compliance, he has kicked it to the congressional leadership to decide whether to enact expedited legislation, which could force a snapback of the sanctions suspended under the deal. Although this would put the U.S. in noncompliance and create great tension with other treaty partners, Trump and Congress could blame one another and the Iranians, even if the Iranians had largely lived up to their commitments. ${ }^{136}$ And the action of hardliners in Washington could perversely strengthen hardliners in Tehran-including the Islamic Revolutionary Guard Corps. So while reformist Iranian President Hassan Rouhani won re-election in May 2017, staking his reputation on the economic benefits of the deal, the future of the JCPOA remains unsure.

What all of this again reminds us is that deals are sticky and global governance regimes are path-dependent. As these regimes develop, they take on a life of their own-building consensus about what set of norms, rules, principles, and decision-making procedures should apply in a particular issue area. Intricate patterns of layered public and private cooperation develop, and formal lawmaking and institutions eventually emerge. These patterns create stiff paths of least resistance from which new political leaders can deviate only at considerable cost. As important, the Iran deal shows the continuing need to apply the smart power strategy of engage-translate-leverage. As the two

135. Keating, supra note 128; see also Kahl, supra note 134 (citing Secretary of State Rex Tillerson) ("[T] $]$ he [P]resident really wants to redo that deal.").

136. See Kahl, supra note 134 ("Iran could withdraw from the JCPOA and resume its march toward a nuclear-weapons capability, and the region would be back on the path to a major war.") 
initial Iran negotiators put it:

The smart way to proceed would be to keep the world's powers united and the burden of proof on Iran[:] relentless [multilateral] enforcement; enhancing sanctions that punish Iran's non-nuclear misbehavior, including its missile program and sponsorship of terrorism; working closely with Arab partners to deter Iran's meddling in their internal affairs; and making plain our concerns with Iran's domestic human rights abuses[ while] using the diplomatic channel we opened with Iran, after 35 years without such contact, to avoid inadvertent escalation. ${ }^{137}$

Most important, there could not be a more inopportune moment for our President to denigrate denuclearization diplomacy and to give our adversaries reason to doubt our willingness to keep our nuclear deals than at this moment, when we face a bona fide nuclear crisis in North Korea.

\section{E. North Korea}

As the Trump Administration began, Vice President Pence intoned that the era of "strategic patience is over." 138 But what precisely does that mean: that we have now entered an era of strategic impatience? Secretary of State Tillerson announced that "all options are on the table" with regard to North Korea. ${ }^{139}$ And in a frightening display of saber-rattling, Donald Trump issued a statement from his vacation home threatening "fire, fury and frankly power the likes of which this world has never seen before." 140 He recently repeated that threat at the United Nations General Assembly, calling Kim Jong-un "Rocket Man" and threatening to. "totally destroy" a country with whom we are not at war and that is populated by more than 25 million people, most of them civilians. ${ }^{141}$

I have visited North Korea three times, most recently in 2000 on an extended trip with Secretary Albright. I found the North Korean leadership extreme, but not suicidal, and certainly rational enough to understand how coun-

137. William J. Burns \& Jake Sullivan, The Smart Way To Get Tough with Iran, N.Y. Times (Sept. 21, 2017) https://www.nytimes.com/2017/09/21/opinion/iran-trump-nuclear-deal-.html [http://perma.cc/7NUE-5VK5].

138. Merrit Kennedy, Pence Tells North Korea: "The Era of Strategic Patience is Over," NPR (Ap. 17, 2017, 10:19 AM), http://www.npr.org/sections/thetwo-way/2017/04/17/524316419/pence-tells-north-koreathe-era-of-strategic-patience-is-overtillers [http://perma.cc/GGT7-VGLJ].

139. Anne Gearan \& Anna Fifield, Tillerson Says "All Options Are on the Table" When It Comes to North Korea, WASH. POST (Mar. 19, 2017), https:/www.washingtonpost.com/world/tillerson-says-alloptions-are-on-the-table-when-it-comes-to-north-korea/2017/03/17/e6b3e64e-0a83-11 e7-bd19-

fd3afa0f7e2a_story.html [http://perma.cc/SNB6-YLDD].

140. Jim Sciutto et al., Trump Promises North Korea 'Fire and Fury' over Nuke Threat, CNN (Aug. 9, 2017, 4:06 AM), http://www.cnn.com/2017/08/08/politics/north-korea-missile-ready-nuclearweapons/index.html [http://perma.cc/AH2A-MLFS]. Senator John McCain responded, "That kind of thetoric, I'm not sure how it helps." Graham Lanktree, Trump's Warning to North Korea Has Nuclear Weapons Experts Chugging Wine, NEwswEEK (Aug. 9, 2017, 7:51 AM), http://www.newsweek.com/north-korea-johnmccain-democrats-and-experts-condemn-donald-trumps-threats-648356 [http://perma.cc/3YH9-DBB4].

141. At U.N., Trump Singles Out 'Rogue' Nations North Korea and Iran, N.Y. TIMES (Sept. 19, 2017), https://www.nytimes.com/2017/09/19/world/americas/united-nations-general-assembly.html [http://perma.cc/7QTV-6U75]. 
terproductive it would be to invite a massive military attack by the United States. But unless we are willing to sacrifice hundreds of thousands of Korean and American lives, no military option is truly viable, especially in a fragile moment when South Korea is just emerging from the recent political turmoil of presidential impeachment. After roiling diplomatic waters by initially declaring that he would consider recognizing Taiwan, Trump has now been schooled by Beijing that he needs Chinese cooperation to put diplomatic pressure on Pyongyang.

Because events from the Korean peninsula are evolving so rapidly-in what some have called a "Cuban Missile Crisis in slow motion"142 - it is obviously treacherous to make predictions about what will happen next. Trump has thrown an unfortunate wild card into the mix: his uncontrolled nuclear rhetoric, to which an unstable Kim Jong-un could too easily overreact. When one can no longer tell whether unhinged words have been spoken by the President of North Korea or of the United States, we face the terrifying prospect that two egotistical, mercurial leaders may engage in a game of nuclear chicken that serves no one's best interest.

But the history of nuclear diplomacy teaches that no nation has surrendered its nuclear weapons under threat. To the contrary, those that have surrendered their arsenals - most prominently Iran and Libya-have done so only when confronted by concerted, unified multilateral diplomacy and relief from sanctions. ${ }^{143}$ A recent historical review found that over the last quarter century, North Korean provocations have usually declined when diplomatic engagement with the United States has increased. ${ }^{144}$ That suggests that the only way out of the North Korean crisis is more intense diplomatic dialogue backed by sanctions. Our diplomatic experts should be talking to their North Korean counterparts almost every day. ${ }^{145}$ The goal of such sustained intense dialogue should be to discourage further nuclear missile testing and to coax

142. David E. Sanger \& William J. Broad, A 'Cuban Missile Crisis in Slow Motion' in North Korea, N.Y. Times (Apr. 16, 2017), https:/www.nytimes.com/2017/04/16/us/politics/north-korea-missile-crisisslow-motion.html [http://perma.cc/GA2Z-TL6D].

143. Steve Coll, The Madman Theory of North Korea, NEw YORKER, (Oct. 2, 2017),

https://www.newyorker.com/magazine/2017/10/02/the-madman-theory-of-north-korea

[http://perma.cc/N9HX-2FY4].

144. See Lisa Collins, Beyond Parallel: 25 Years of Negotiations and Provocations: North Korea and the United States, CSIS, https://beyondparallel,csis.org/25-years-of-negotiations-provocations/ [http://perma.cc/YM4H-NZUK].

145. Secretary of State Tillerson recently confirmed that some kind of direct dialogue with North Korea is in fact occurring. See David Sanger, U.S. in Direct Communication with North Korea, Says Tillerson, N.Y. Times (Sept. 30, 2017) (quoting Secretary Tillerson) ("We have a couple, three channels open to Pyongyang... mark[ing] the first sign that the Trump administration has been trying its own version of what the Obama [A]dministration did with Iran: using a series of backchannel, largely secret communications that, after years of negotiation, resulted in a nuclear accord."), https://www.nytimes.com/2017/09/30/world/as ia/us-north-korea-tillerson.html [http://perma.cc/ETU2-6XAT]. But it is unclear that the President himself supports this diplomatic initiative. See Donald J. Trump (@realDonaldTrump), TwITTER (Oct. 1, 2017, 9:30 AM) ("I told Rex Tillerson ... that he is wasting his time trying to negotiate with Little Rocket Man ...."), https://twitter.com/realDonaldTrump/status/914497877543735296 [http://perma.cc/3TNW-V3CK]. 
the North Koreans to accept a new iteration of the Six Party Talks (the two Koreas, Russia, China, Japan, Taiwan, and the United States), a historic multiparty dialogue that resulted from North Korea's 2003 withdrawal from the Nuclear Non-Proliferation Treaty and that (until its discontinuation in 2009) modeled the kind of diplomatic dialogue that generated the Iran Nuclear Deal. The election of South Korean President Moon Jae In, a politician committed to dialogue with the North, raises the additional prospect of new "good copbad cop"-style negotiations.

When all is said and done, Trump's bellicose rhetoric has not altered America's main policy alternative for North Korea, which remains international law as smart power. ${ }^{146}$ After vociferous initial criticism of the ObamaClinton North Korea strategy, the Trump Administration has little choice but to revert to a variant of the Obama Administration's past policies. As the Iran Nuclear Deal shows, an engage-translate-leverage approach would combine at least six elements: containment through renewed sanctions of the kind voted on by the U.N. Security Council in August 2017 ${ }^{147}$; deterrence through coordinated U.S.-ROK military cooperation; intense multilateral diplomacy with a special focus on North Korea's horrifying human rights record ${ }^{148}$; an accelerated surveillance and cybersabotage program; and enhanced diplomatic pressure by China, all with an eye toward eventually reviving the Six Party Talks as an ongoing diplomatic forum to discuss a standstill to the North Korean nuclear program in exchange for the food, energy, sanctions relief, and international recognition that Kim Jong-un so clearly craves. ${ }^{149}$

But if this option is to have a chance, the most critical step that President Trump can take with respect to North Korea is to continue to abide by the Iran Nuclear Deal. For the United States cannot persuade Kim Jong-un to listenor use its smart power to encourage Russia, China, and our European allies to keep the pressure on him-unless all of those nations believe that the United States will stick by that deal, particularly if it ensures greater IAEA visibility into North Korean nuclear activities. Ultimately, America's only realistic option in North Korea-negotiating and abiding by a painstakingly negotiated

146. Susan Rice, It's Not Too Late on North Korea, N.Y. TIMES (Aug. 10, 2017), https:/www.nytimes.com/2017/08/10/opinion/susan-rice-trump-north-korea.htm] [http://perma.cc/MX2H$\mathrm{KS} 3 \mathrm{H}]$.

147. Adam Taylor, What the New U.N. Sanctions on North Korea Mean, WASH. PosT (Aug. 7, 2017), https://www. washingtonpost.com/news/worldviews/wp/2017/08/07/what-the-new-u-n-sanctions-on-northkorea-mean/ [http://perma.cc/B7AE-4ALQ]; Reuters, Here are the UN's Harsh New Sanctions on North Korea, FORTUNE (Nov, 30, 2016), http://fortune.com/2016/12/01/un-sanctions-north-korea-coal-statues/ [http://perma.cc/4M9Q-D8GA] (noting the slashing of North Korea's annual coal export revenue by $60 \%$ as well as copper, nickel, silver and zinc exports and the sale of symbolic statues).

148. William Tobey, 'No Good Options' on North Korea Is a Myth, ForeIGN PoL'Y (July 7, 2017, 8:28 AM), http://foreignpolicy.com/2017/07/07/no-good-options-on-north-korea-is-a-myth [http://perma.cc/XJ3CKCC9].

149. Jeffrey A. Bader, Why Deterring and Containing North Korea Is Our Least Bad Option, BROOKINGS (Aug. 8, 2017), https://www.brookings.edu/blog/order-from-chaos/2017-08-08/why-deterringand-containing-north-korea-is-our-least-bad-option [http://perma.cc/3JUV-H8UB]. 
multilateral deal-will end up looking a lot like the "strategic patience" policy that Trump supposedly rejected.

\section{F. Russian Hacking and Cybersecurity}

All of the U.S. intelligence agencies investigating the incident have now agreed that Russia hacked the 2016 presidential election. They found that Russia's President Putin did so with an eye toward undermining public faith in the U.S. democratic process, denigrating Hillary Clinton, and helping to elect Donald Trump. ${ }^{150}$ The multiple investigations currently proceeding before the House and Senate Intelligence Committees - not to mention the first grand jury indictments recently brought by Special Counsel Robert Mueller ${ }^{151}$ — all focus on, inter alia, possible Russian collusion with U.S. persons around election manipulation. These investigations should in time tell us precisely what violations of domestic law may have occurred.

Even without these investigatory findings, based on what we already know, there seems little doubt that the Russian hack violated international law. Although the international law of cyberspace is in its infancy, ${ }^{152}$ even if the Russians did not actually manipulate polling results, illegal coercive interference in another country's electoral politics - including the deliberate spreading of false news - constitutes a blatant intervention in violation of international law. The most prominent group of experts writing on cyberwar and cybersecurity has declared that "[i]llegal coercive interference could include manipulation of elections or of public opinion on the eve of elections, as when online news services are altered in favo[] $\mathrm{r}$ of a particular party, false news is spread, or the online services of one party are shut off."153 An external attempt to distort the information that voters possess when they go to the

150. Off. of the Dir. of Nat'l Intelligence, BACKGROUND To "AsSESSING RUSSIAN ACTIVITIES AND INTENTIONS IN RECENT US ELECTIONS": THE ANALYTIC PROCESS AND CYBER INCIDENT ATTRIBUTION (Jan. 6, 2017), https://www.dni.gov/files/documents/ICA_2017_01.pdf [http://perma.cc/BZG6-U65J].

151. Remarkably, we have now learned that an FBI counterintelligence probe has been ongoing since July 2016 to determine the extent of Russian interference and possible collusion with U.S. persons. Julian Borger \& Spencer Ackerman, Trump-Russia Collusion Is Being Investigated by FBI, Comey Confirms, GUARDIAN (Mar. 20, 2017), https://www.theguardian.com/us-news/2017/mar/20/fbi-director-comeyconfirms-investigation-trump-russia [http://perma.cc/B5ZK-36HJ]. However, then-FBI Director Comey did not report publicly on this, choosing instead to publicize various matters around Hillary Clinton's emails. Natasha Bertrand, Comey Successfully Dodged the Biggest Question Looming over the Trump-Russia Probe, BUS. INSIDER (May 4, 2017, 6:03 PM), www.businessinsider.com/comey-did-not-disclose-trump-russiaprobe-testimony-2017-5 [http://perma.cc/H9SK-W33B].

152. See generally Harold Hongu Koh, International Law in Cyberspace, 54 HARV. INT'L. L.J. ONLINE 1, 2-7 (2012), http://digitalcommons.law.yale.edu/fss_papers/4854/[http://perma.cc/4J78-35YG].

153. TallinN Manual 2.0 ON the International Law applicable to Cyber Operations (2d ed. 2017); see also Koh, International Law in Cyberspace, supra note 152, at 2-7 (stating the U.S. government legal position that international law applies in cyberspace; that under certain circumstances, the use of cybertools may constitute a "use of force"; and that states are legally responsible for the actions of proxy actors); see also Michael N. Schmitt, International Law in Cyberspace: The Koh Speech and Tallinn Manual Juxtaposed, 54 HARV. INT'L. L.J. ONLINE 13 (2012) (providing a concordance between positions stated in my official speech and the unofficial Tallinn Manual), http://www.harvardilj.org/wp-content/uploads/2012/12/HILJOnline_54_Schmitt.pdf [http://perma.cc/T465-NAPH]. 
polls also violates the human rights of the electors under the International Covenant on Civil and Political Rights. ${ }^{154}$

While we do not yet know the full story of this sorry episode, plainly, this is not a partisan issue, and it could well recur soon, in the United States or abroad. ${ }^{155}$ Given these manifest violations, the recommended response would be to engage-translate-leverage. Ideally, the United States would diplomatically engage the Russians, seek acknowledgement that their actions were illegal or inappropriate, translate from emerging cyberlaw and existing human rights law to articulate the international norms violated, and then seek to leverage from that piece of state practice to a policy outcome whereby Russia would foreswear future hacking misadventures.

Before he left office, President Obama began that process with a calibrated, lawful response under international law: expelling a number of Russian diplomats and closing spy facilities within the United States. Shortly after the 2016 election, the Obama Administration issued a legal interpretation. Without mentioning Russia by name, my successor as State Department Legal Adviser publicly cautioned that "a cyber operation by a State that interferes with another country's ability to hold an election or that manipulates another country's election results would be a clear violation of the rule of nonintervention." 156 But attempts to leverage those first two understated steps into a broader political outcome have been disrupted by the Trump Administration's mercurial behavior. While repeatedly calling the various investigations a "witch hunt," President Trump has at various points threatened to retract, or potentially modify, President Obama's response to the hacking. At this writing, however, he still has not yet followed through on those threats. ${ }^{157}$ Meanwhile, Congress has now passed a sweeping Russian sanctions bill by veto-proof margins, and the President has reluctantly signed it. ${ }^{158}$

154. International Covenant on Civil and Political Rights, supra note 27, art. 25 ("Every citizen shall have the right and the opportunity, without ... unreasonable restrictions: (b) To vote and to be elected at genuine periodic elections which shall be by universal and equal suffrage and shall be held by secret ballot, guaranteeing the free expression of the will of the electors.").

155. French President Emmanuel Macron claimed that he was hacked during the French presidential campaign. Aurelien Breeden et al., Macron Campaign Says It Was Target of 'Massive' Hacking Attack, N.Y. TIMES (May 5, 2017), https:/www.nytimes.com/2017/05/05/world/europe/france-macron-hacking.html [http:/perma.cc/XGU4-GGGK]. According to Republican Senator Marco Rubio, the Russians tried to hack him earlier this year. Emmarie Huetteman, Marco Rubio Says His Campaign Was a Target of Russian Cyberattacks, N.Y. TIMES (Mar. 30, 2017), https://www.nytimes.com/2017/03/30/us/politics/marco-rubiorussian-cyberattacks.html [http://perma.cc/BRZ7-JCPZ].

156. See Brian J. Egan, Remarks on International Law and Stability in Cyberspace (Nov. 10, 2016), https:/2009-2017.state.gov///1/releases/remarks/264303.htm [http://perma.cc/3XH4-DTTW].

157. See Donald J. Trump (@realDonaldTrump), TwITTER (May 18, 2017, 4:52 AM), https://twitter.com/realdonaldtrump/status/865173176854204416 [http://perma.cc/UY3L-QQF4]; see also Glenn Thrush, Trump, on Twitter, Targets Obama and Russia, N.Y. TIMES (June 26, 2017), https:/www.nytimes.com/2017/06/26/us/politics/trump-twitter-obama-russia.html [http:/perma.cc/7HMNJV8D].

158. Natalie Andrews \& Rebecca Ballhaus, Trump Signs-and Slams-Russia Sanctions, WaLl ST. J. (Aug. 2, 2017, 8:35 PM), https:/www.wsj.com/articles/president-trump-signs-sanctions-bill-aimed-atpunishing-russia-for-election-meddling-1501685839 [http://perma.cc/QUH4-N766]. 
One lingering question is whether the United States should now use its cyberassets to punish Russian hackers directly, such as by trying to knock them offline or damaging their hardware, once we meet the burden of proof for attribution of proxy acts to official actors. ${ }^{159}$

Unfortunately, the Trump Administration's continuing reluctance even to acknowledge that the hacking has occurred has given cover to Putin's refusal to accept responsibility for his actions. Instead, Russia has now vowed an aggressive pushback against the new congressional sanctions. ${ }^{160}$ As a result, the Russian hack stands in the way of rationalizing other aspects of U.S. policy toward Russia going forward. These include Russia's intense desire to get sanctions lifted; the human rights issues surrounding Putin's treatment of demonstrators and what one commentator called a "trail of dead Russians"161; and the continuing need for the United States and Russia to remain engaged with one another - even within a now-strained relationship-regarding such thorny unresolved issues as Syria, IS, Iran, and Ukraine.

\section{G. Ukraine}

Ukraine is another area where, despite blatant Russian intervention, a hard-power ouster does not appear to be a live option. With then-Vice President Joe Biden taking the lead, the Obama Administration sought to pursue an engage-translate-leverage strategy: engaging with the European Union and the Organization for Security and Cooperation in Europe in direct dialogue regarding Ukraine, translating norms of nonintervention to make it clear that the United States considered Russia's invasion of Ukraine and its seizure of oil reserves in Crimea blatantly illegal, and trying to leverage these elements into a broader "Minsk II" diplomatic process aimed at securing a fairer longterm outcome more respectful of democracy and human rights.

When Russia brushed these efforts aside, Ukraine took matters into its own hands and triggered its own set of interactions designed to generate legal interpretations that could ultimately be internalized into Russian domestic conduct. ${ }^{162}$ When the Obama Administration left office, the new Administration ceased robust engagement with Russia on Ukraine, and Ukraine's efforts to seek international justice took on new meaning. Just before Trump's inau-

159. See James Stavridis, How to Win the Cyberwar Against Russia, ForeIGN POL'Y (Oct. 12, 2016), https://foreignpolicy.com/2016/10/12/how-to-win-the-cyber-war-against-russia [http://perma.cc/VU5VPVFK] (Dean of the Fletcher School of Law and Diplomacy, and formerly U.S. Navy admiral, making these suggestions).

160. Russia Expels 755 US Diplomats in Response to Sanctions, AL JAZEERA (July 30, 2017), www.aljazeera.com/news/2017/07/russia-expels-755-diplomats-response-sanctions-170730201720880.html [http://perma.cc/TT85-TA5M].

161. Russian and 2016 Elections: Hearing Before the S. Select Intelligence Comm., 115th Cong. (2017) (statement of Clinton Watts, Senior Fellow, George Washington University Center for Cyber and Homeland Security).

162. I should disclose that I have served as a counsel to Ukraine on a number of these litigation matters. 
guration, Ukraine brought an application against Russia before the International Court of Justice in The Hague (ICJ), alleging that Russia had violated the Terrorism Financing Convention with its actions in Eastern Ukraine, particularly in allowing a Buk missile to enter Ukraine in 2014 that was then used to shoot down a civilian Malaysian aircraft, MH-17. The lawsuit further alleged that Russia's systematic discriminatory actions in Crimea against Crimean Tatars and ethnic Ukrainians violated Russia's obligation under the Convention for the Elimination of Racial Discrimination (CERD). In April 2017, the Court issued an order for provisional measures against Russia on the CERD issue and also made clear its expectation that Russia would both honor the Terrorism Financing Convention during the duration of the litigation and honor its commitments in the Minsk II process, which include stopping the flow of weapons to illegal groups in Ukraine. ${ }^{163}$

In the face of a flagging multilateral diplomatic process and baffling passivity toward Russian adventurism by the Trump Administration, Ukraine has been able to deploy transnational legal process as part of a broader response to Russian aggression. A judgment from the ICJ could help strengthen a collective response to Russia's adventurism and delegitimize Putin's actions, making implementation of the Minsk II process more likely. At the same time, Ukraine has combined its ICJ litigation with other cases: a challenge to the seizure of Crimean oil reserves before the International Tribunal for the Law of the Sea, as well as investor-state arbitrations under a bilateral investment treaty regarding expropriation and illegal interference by Russia with investments in Ukraine. ${ }^{164}$

While it is too early to tell whether these various international lawsuits will succeed, they have plainly allowed Ukraine to seize back the initiative, put Russia on the defensive, and fill some of the vacuum left by the Trump Administration's refusal to challenge Putin publicly. By bringing these transnational claims, Ukraine has been able to directly contest Russia's actions in various tribunals capable of passing on the legality of those actions, reasserting itself as an independent player confronting Russia within the transnational legal process.

163. Application of the International Convention for the Suppression of the Financing of Terrorism and of the International Convention on the Elimination of All Forms of Racial Discrimination (Ukr. v. Russ.), Order, (Apr. 19, 2017), http://www.icj-cij.org/files/case-related/166/19394.pdf [http://perma.cc/S6C2D6MF]; Beth Van Schaack, The ICJ Issues Provisional Measures Against Russia on Ukraine's Racial Discrimination Claims, JUST SECURTY (Apr. 20, 2017, 2:19 PM), https://www.justsecurity.org/40138/icj-issuesprovisional-measures-russia-ukraines-racial-discrimination-claims [http://perma.cc/8LUN-GJJ8].

164. Gaiane Nuridzhanyan, Ukraine vs. Russia in International Courts and Tribunals, EJIL: TALK! (Mar. 9, 2017), https://www.ejiltalk.org/ukraine-versus-russia-in-international-courts-and-tribunals [http://perma.cc/T3WR-VG2K]. 


\section{H. Al Qaeda and IS}

As I have detailed elsewhere, in its counterterrorism efforts over the last decade, the United States has taken substantial steps to outline an emerging law of 21 st-century war. ${ }^{165}$ President Obama sought to narrow an endless "war on terror" into a narrower armed conflict in which drones and other tools are used to dismantle specific non-state transnational networks that threaten the United States, such as Al Qaeda and Daesh, or IS (the so-called "Islamic State"). Under these principles, the United States is at war not with "terror" generally, but with a specific transnational terror network that links Al Qaeda, the Taliban, and associated forces.

Within this narrower armed conflict, drones are a legally available tool, not a strategy. Unlike torture, which is always illegal, the use of drones can be lawful in wartime, depending on the precise facts regarding how they are used. ${ }^{166}$ Drones can be used as part of a much broader collective "smart power" response to terrorism, whereby the United States engages with its allies; translates from the existing laws of war in an effort to integrate lawful targeting and detention into a broader smart power strategy; and leverages limited uses of force with strong legal tools, such as diplomacy, development, and cooperative law enforcement.

President Obama detailed this approach in a wide-ranging speech delivered at the National Defense University in May 2013. ${ }^{167}$ In that speech, the President made clear America's preference for capture over kill and respect for state sovereignty. ${ }^{168} \mathrm{He}$ also expressed a commitment to the notion that self-defense may be invoked to use force against a continuing imminent threat (based on a necessarily elongated notion of "imminence"169) against senior operational leaders who are clearly determined to strike against the United States, so long as there is a "near-certainty that no civilians will be killed or injured." 170 In December 2016, the Obama Administration finally embedded these principles into a comprehensive "legal and policy frameworks" docu-

165. See generally Harold Hongu Koh, The Emerging Law of 21st Century War, 66 EMORY L.J. 487 (2017) (from which this subpart derives).

166. While some weapons (for example, chemical weapons) are per se illegal, drones - such as bombs or precision-guided missiles-can be used lawfully or not depending upon exactly how they are targeted. So if you hear someone say, "We should get the lawyers off the backs of the generals," your answer should be, "Don't you dare!" It is the fact that lawyers are there advising the generals about what is or is not lawful that determines whether a particular act is a lawful act of war or an illegal summary execution.

167. President Barack Obama, Remarks by the President at the National Defense University, THE WHITE House (May 23, 2013),

https://www.whitehouse.gov/the-press-office/2013/05/23/remarks-president-national-defense-university [http://perma.cc/6J6Y-C3B6].

168. Id.

169. See Jeremy Wright, Att'y Gen., U.K., Speech to the International Institute for Strategic Studies: The Modern Law of Self-Defence, GOV.UK (Jan. 11, 2017),

https://www.gov.uk/government/speeches/attorney-generals-speech-at-the-international-institute-forstrategic-studies [http://perma.cc/S6AA-Q8QD]; see generally Sir Daniel Bethlehem, Self-Defense Against an Imminent or Actual Armed Attack by Nonstate Actors, 106 AM. J. INT'L L. 770, 770-72, 774, 776 (2012).

170. Obama, supra note 167 . 
ment, which offered a detailed exposition of how the various U.S. practices developed during that Administration are consistent with the laws of war. ${ }^{171}$

Under traditional laws of war, the United States is obliged to follow both the law of initiating war (jus ad bellum) and the law of conducting war (jus in bello). Under domestic law, the United States must follow the terms of both the Constitution and the various statutory authorizations for, and restrictions on, the use of military force. ${ }^{172}$ Since the second half of the George W. Bush Administration, the United States has asserted that it is in a non-international armed conflict with $\mathrm{Al}$ Qaeda, the Taliban, and associated forces in response to the 9/11 attacks and may use force consistent with the laws of war and its inherent right to self-defense. Under this theory, the Obama Administration construed IS to be a successor to Al Qaeda, as a splinter or offshoot of $\mathrm{Al}$ Qaeda Core, that entered the fight against the United States alongside other armed groups in such active theaters of battle as Afghanistan, Iraq, and Syria. ${ }^{173}$ As a matter of international law, until its recent disengagement, Russia said it had been invited to fight in Syria by Assad's government. ${ }^{174}$ The United States is participating there against IS based not on Assad's consent, but rather because it acts in collective self-defense of Iraq.

The lawfulness of our actions is an issue fundamental to the legitimacy of U.S. counterterrorism policy. Yet based on recent reporting, it remains unclear how scrupulously these legal and policy rules-particularly the rules to ensure that civilians are not targeted-are being followed by the new Trump

171. See FRAMEWORKS REPORT, supra note 78. After this lecture was delivered, the President also issued an executive order calling for regular disclosure of civilian casualty statistics. See id. at 26-27; United States Policy on Pre- and Post-Strike Measures to Address Civilian Casualties in U.S. Operations Involving the Use of Force, 81 Fed. Reg. 44,485 (July 1, 2016); see also Charlie Savage \& Scott Shane, U.S. Reveals Death Toll from Airstrikes Outside War Zones, N.Y. TIMEs (July 1, 2016), http://www.nytimes.com/2016/07/02/world/us-reveals-death-toll-from-airstrikes-outside-of-war-zones.html [http://perma.cc/6CEN-D6UK]. In my view, more steps toward transparency and standard-setting should still be taken. See Harold Hongju Koh, Remarks at the Oxford Union: How to End the Forever War? 14 (May 7, 2013), available at http://opiniojuris.org/wp-content/uploads/2013-5-7-corrected-koh-oxford-union-speechas-delivered.pdf [http://perma.cc/VPJ5-STC8] ("[T] he real issue . . is not drone technology per se, but the need for transparent, agreed-upon domestic and international legal process and standards.") (emphasis omitted).

172. See, e.g., Authorization for Use of Military Force, Pub. L. No. 107-40, § 2(b), 115 Stat. 224, 224 (2001).

173. For more detailed discussion of the Administration's legal theory for using force against ISIL, see FRAMEWORKS REPORT, supra note 78, at 4, 11; Harold Hongju Koh, Obama's ISIL Legal Rollout: Bungled, Clearly. But Illegal? Really?, JUST SECURITY (Sept. 29, 2014, 8:03 AM),

https://www.justsecurity.org/15692/obamas-isil-legal-rollout-bungled-clearly-illegal-really

[http://perma.cc/4RC2-VRG6]. A recent lawsuit, Smith v. Obama, which challenged the domestic legality of that legal theory, was dismissed both for lack of standing and as a political question but is currently pending on appeal before the D.C. Circuit. See No. 16-843 (D.D.C. Nov. 21, 2016) (mem.); Charlie Savage, Suit Calling War on ISIS Illegal Is Rejected, N.Y. TIMES (Nov. 21, 2016), $\mathrm{http}: / /$ www.nytimes.com/2016/11/21/us/politics/judge-lawsuit-war-isis.html [http://perma.cc/8J97-EUUZ]. But see Marty Lederman, Judge Kollar-Kotelly Dismisses Captain Smith's Suit, JuST SeCURITY (Nov. 22, 2016, 8:05 AM), https://www.justsecurity.org/34778/judge-kollar-kotelly-dismisses-captain-smiths-suit [http://perma.cc/DS8H-7F4X] (challenging court's political question ruling).

174. Nick Robins-Early, Russia Says Its Airstrikes in Syria Are Perfectly Legal. Are They?, HUFFINGTON POST (Oct. 1, 2015, 5:33 PM), http:/www.huffingtonpost.com/entry/russia-airstrikessyriainternationallaw_us_560d6448e4b0dd85030b0c08 [http://perma.cc/LRK4-TQG4]. 
Administration. ${ }^{175}$ Nor did President Trump's recent speech on his Afghanistan strategy clarify much beyond his intention to maintain an unspecified number of troops there for the indefinite future. ${ }^{176}$ Significantly, despite Trump's decision to lift the Obama rules for Somalia, the U.S. military commander for the African Command continued to apply the "near certainty" standard against civilian deaths. ${ }^{177}$ But in Yemen, by contrast, Trump lifted these restrictions just before a disastrous raid that killed many civilians. ${ }^{178}$ In September 2017, the Trump Administration finally announced its replacement of Obama's Presidential Policy Guidance with a new, apparently looser framework. ${ }^{179}$ But an initial read of that document leaves unclear exactly how much the drone rules have really been loosened. ${ }^{180}$

With respect to IS, the United States is completing a huge struggle in Mosul, Iraq, and Raqqa, Syria. ${ }^{181}$ But use of hard power against IS in these strongholds also formed a key piece of Hillary Clinton's plan for fighting IS ${ }^{182}$ - to take out these strongholds by intensifying the air campaign and stepping up support for local forces on the ground. While these are important steps, the Islamic State is still alive, and America has only shown again its impressive capacity to exercise hard power. ${ }^{183}$ But what remains underdeveloped or missing from the government's program are the smart-power pieces of the Clinton strategy, particularly pursuit of a diplomatic strategy to resolve Syria's civil war and Iraq's sectarian conflict between Sunnis and

175. Micah Zenko, Why Is the U.S. Killing So Many Civilians in Syria and Iraq?, N.Y. TIMEs (June 19, 2017), https://www.nytimes.com/2017/06/19/opinion/isis-syria-iraq-civilian-casualties.html [http://perma.cc/T5E8-SDS6].

176. President Donald Trump, Remarks by President Trump on the Strategy in Afghanistan and South Asia, THE WHITE HouSE (Aug. 21, 2017), https://www.whitehouse.gov/the-press-office/2017/08/21/remarkspresident-trump-strategy-afghanistan-and-south-asia [http://perma.cc/7ZXU-QR3E].

177. Helene Cooper, Navy SEAL Who Died in Somalia Was Alongside, Not Behind, Local Forces, N.Y. Times (May 9, 2017), https://mobile.nytimes.com/2017/05/09/world/africa/somalia-navy-seal-kylemilliken.html [http://perma.cc/P6TL-73VZ].

178. Eric Schmitt \& David E. Sanger, Raid in Yemen: Risky from the Start and Costly in the End, N.Y. TIMES (Feb. 1, 2017), https://www.nytimes.com/2017/02/01/world/middleeast/donald-trump-yemencommando-raid-questions.html [http://perma.cc/9SKF-V2EH] (noting that "[a]fter initially denying there were any civilian casualties, Pentagon officials backtracked somewhat on Sunday after reports from the Yemeni authorities begin [sic] trickling in and grisly photographs of bloody children purportedly killed in the attack appeared on social media sites affiliated with Al Qaeda's branch in Yemen. Capt. Jeff Davis, a Pentagon spokesman, said on Monday that some of the women were combatants").

179. See Charlie Savage \& Eric Schmitt, Trump Poised to Drop Some Limits on Drone Strikes and Commando Raids, N.Y. Times (Sept. 21, 2017), https://www.nytimes.com/2017/09/21/us/politics/trumpdrone-strikes-commando-raids-rules.html [http://perma.cc/SVX5-G4LB].

180. See Luke Hartig, Trump's New Drone Strike Policy: What's Any Different? Why It Matters, JusT SECURITY (Sept. 22, 2017, 8:01 AM), https://www.justsecurity.org/45227/tnumps-drone-strike-policydifferent-matters [http://perma.cc/7QSY-73JT].

181. Michael R. Gordon, U.S.-Backed Forces Close to Trapping ISIS Holdouts in Raqqa, N.Y. TIMES (July 2, 2017), https://www.nytimes.com/2017/07/02/world/middleeast/us-backed-forces-close-to-trappingisis-holdouts-in-raqqa.html [http://perma.cc/7VMQ-5NCC].

182. Hillary Clinton's Comprehensive Plan to Defeat ISIS and the Threat of Radical Jihadism, HILLARYCLINTON.COM, https://www.hillaryclinton.com/briefing/factchecks/2016/09/07/hillary-clintonscomprehensive-plan-to-defeat-isis-and-the-threat-of-radical-jihadism [http://perma.cc/4XH8-E869].

183. See Antony J. Blinken, The Islamic State Is Not Dead Yet, N.Y. TIMES (July 9, 2017), https://www.nytimes.com/2017/07/09/opinion/islamic-state-mosul-iraq-strategy.html [http://perma.cc/ZKU6CM5Y]. 
Shias-both of which have contributed to the rise of IS. Nor is it clear what steps, if any, the Trump Administration is taking to cut off IS's supplies, money, arms, propaganda, and fighters.

The conflict against IS is taking place not just in Iraq and Syria but also online and in the homelands of North America and Europe. The United States must also mobilize smart-power cybertools and public diplomacy to lead a concerted effort to discredit IS ideology online: stop digital recruitment strategies; harden homeland defenses; use an "intelligence surge" to build resilience at home; and make concerted individual and collective law enforcement efforts to discover and disrupt terrorist plots before they occur. Although this broader smart-power approach requires the new Administration to maintain strong alliances, particularly with Canada and Europe, in his earliest diplomatic conversations President Trump has placed those alliances under extraordinary strain, including with his ill-considered Muslim Ban.

Going forward, the most critical aspect of the United States counterterrorism approach will be its perceived legality. A canary in the coal mine will be the Trump Administration's treatment of homegrown sympathizers "inspired" by Al Qaeda or IS and how it distinguishes criminal acts from acts of war. Under the Obama theory, such self-radicalized individuals are considered imitators, not "members," of these terrorist organizations and hence most fit for criminal prosecution, not military action. And the United States has long successfully prosecuted horrific acts of terrorism within our civilian criminal justice system.

In the months ahead, we must beware the "self-generated 9/11." Suppose Trump's Travel Ban inspires a Muslim-American residing in the United States to get a gun, shoot up a nightclub, and then post on Facebook that he supports Al Qaeda and IS. Our criminal justice system has a long and wellestablished history of swiftly trying and punishing such acts. That scenario will present no reason to bestow any new authorities on the executive branch, to send that person to Guantanamo, or to try that person before the struggling military commissions on the false claim that we cannot trust "so-called judges" to protect our safety. Self-radicalized criminals should be subject to law enforcement, not warfare. Oklahoma City bomber Timothy McVeigh plotted and executed an attack that killed three hundred people, but he was given due process, represented, tried, convicted, and executed all within a civilian setting. ${ }^{184}$ Similarly, Dzhokhar Tsarnaev, the younger Boston Marathon bomber, was fully represented, convicted, tried, and sentenced in an Article III court, during a time when the cumbersome post-9/11 military commission

184. Douglas O. Linder, The Oklahoma City Bombing and the Trial of Timothy McVeigh: A Chronology, FAMOUS TRIALS, http://www.famous-trials.com/oklacity/715-chronology [http://perma.cc/SXN4-8HKN] (last visited Oct. 26, 2017). The recent case of the 2017 New York Halloween killer, Sayfullo Saipov, strongly evokes the hypothetical case described in text. 
system achieved no meaningful convictions. ${ }^{185}$ As the Trump Administration's counterterrorism strategy evolves, its perceived legality under both international and domestic law will prove key to whether other transnational actors will continue to support the broader U.S. approach or rather, choose to challenge it as illegal before courts and other transnational fora.

\section{Syria}

That brings us finally to the vexing issue of Syria, the greatest humanitarian tragedy of our time. Six years of civil war have witnessed more than 450,000 Syrian deaths, 6 million internally displaced, and 5 million refugees, some 2 million of them children. ${ }^{186}$ I have elsewhere suggested a broader approach to this complex problem, which includes at least five elements ${ }^{187}$ : (1) fighting the IS; (2) pursuing accountability for Assad and other leading war criminals; (3) responses to Assad's attacks on civilians (e.g., safe zones, ceasefires, responses to the use of chemical weapons); (4) energizing the peace process; and (5) the refugee crisis, which has strained the frontline states and disrupted Europe. Simply put, the debacle has grown out of Assad's brutality, eight Russian vetoes, and no viable peace process. Here, too, the key question has been how to add a lawful hard-power element to the effort without undermining the soft-power strategy to solve the overall crisis. The absence of a threat of lawful force has crippled effective diplomacy and created a mismatch between broader policy objectives and available softpower tools.

Is doing nothing in Syria our only option? Or is there a lawful option that would enable the United States to use Richard Holbrooke-style "diplomacy backed by force" to prevent outrageous attacks on civilians-particularly those employing chemical weapons - and to jumpstart diplomacy, achieve a durable ceasefire, and move eventually toward a Syrian version of the Dayton Peace Accords? During the 2016 presidential campaign debates, three of the four national candidates-Hillary Clinton, Tim Kaine, and Trump's vicepresidential candidate Mike Pence - argued that the United States should use limited military force in Syria to create a humanitarian corridor and no-fly zone. ${ }^{188}$ The Obama Administration argued that a no-fly zone would not achieve the humanitarian results that those who supported it desired but con-

185. Andy Thibault et al., Tsarnaev Sentenced to Death in Boston Bombing Trial, NBC NEwS (May 15, 2015, 4:50 PM), http://www.nbcnews.com/storyline/boston-bombing-trial/boston-bombing-trial-juryreaches-verdict-penalty-phase-n359731 [http://perma.cc/L9T2-6EPP].

186. Syrian Civil War Fast Facts, CNN (July 8, 2017, 10:12 AM),

http://www.cnn.com/2013/08/27/world/meast/syria-civil-war-fast-facts/index.html [http://perma.cc/8BV47ZWQ].

187. See Koh, The Emerging Law of 21st Century War, supra note 165, at 504-11.

188. Mark Landler, Syria Draws a Rare Source of Accord in Debate Between Kaine and Pence, N.Y. TIMES (Oct. 5, 2016), https:/www.nytimes.com/2016/10/06/us/syria-vice-presidential-debate.html [http://perma.cc/V7VF-T9L7]. 
tinuously reviewed the possibility of various forms of direct intervention in Syria. Donald Trump argued vociferously against further involvement in Syria. But on April 6, 2017, following reports that Assad had again used chemical weapons against civilians, including small children, the new President abruptly reversed course and launched missile strikes against Assad's forces. ${ }^{189}$

Although I am obviously no fan of this Administration, I have argued elsewhere that under emerging international law, the Trump Administration's April 6 strikes against Syria were not illegal. ${ }^{190}$ This view also seems to align with the view of several key governments who supported the action in the days after the attacks. ${ }^{191}$ The United Kingdom, Denmark, and Belgium have all articulated the conditions under which they believe humanitarian intervention to be lawful. ${ }^{192}$ But the United States has remained quiet. President Obama began his presidency by saying that he believed in humanitarian intervention, but his administration never publicly stated a legal test. ${ }^{193}$ In the

189. Michael R. Gordon et al., Dozens of U.S. Missiles Hit Air Base in Syria, N.Y. TIMES (Apr. 6, 2017), https:/www.nytimes.com/2017/04/06/world/middleeast/us-said-to-weigh-military-responses-to-syrianchemical-attack.html [http:/perma.cc/D76A-LNAR].

190. See Harold Hongju Koh, Not Mlegal: But Now the Hard Part Begins, Just SECurity (Apr. 7, 2017), https://www.justsecurity.org/39695/illegal-hard-part-begins [http://perma.cc/ZVF8-9GQZ] (explicating and applying the following test offered in Harold Hongju Koh, The War Powers and Humanitarian Intervention, 53 HOUS. L. REV. 971,1011 (2016):

(1) If a humanitarian crisis creates consequences significantly disruptive of international orderincluding proliferation of chemical weapons, massive refugee outflows, and events destabilizing to regional peace and security-that would likely soon create an imminent threat to the acting nations (which would give rise to an urgent need to act in individual and collective self-defense under U.N. Charter Article 51);

(2) a Security Council resolution were not available because of persistent veto; and the group of nations that had persistently sought Security Council action had exhausted all other remedies reasonably available under the circumstances, they would not violate U.N. Charter Article 2(4) if they used

(3) limited force for genuinely humanitarian purposes that was necessary and proportionate to address the imminent threat, would demonstrably improve the humanitarian situation, and would terminate as soon as the threat is abated.

In particular, these nations' claim that their actions were not wrongful would be strengthened if they could demonstrate:

(4) that the action was collective, e.g., involving the General Assembly's Uniting for Peace Resolution or regional arrangements under U.N. Charter Chapter VIII;

(5) that collective action would prevent the use of a per se illegal means by the territorial state, e.g., deployment of banned chemical weapons; or

(6) would help to avoid a per se illegal end, e.g., genocide, war crimes, crimes against humanity, or an avertable humanitarian disaster, such as the widespread slaughter of innocent civilians, for example, another Halabja or Srebrenica. To be credible, the legal analysis of any particular situation would need to substantiate each of these factors with persuasive factual evidence of: (1) Disruptive Consequences Likely to Lead to Imminent Threat; (2) Exhaustion; (3) Limited, Necessary, Proportionate, and Humanitarian Use of Force; (4) Collective Action; (5) Illegal Means; and (6) Avoidance of Illegal Ends.

[While it was] early to judge whether the Trump Administration's April 6 actions satisfy this standard, particularly points (3) and (4)[,] if they did, recognition of a customary international law 'affirmative defense' against a claim of Article 2(4) violation would" provide an ex post exemption from legal wrongfulness.

191. Julian Ku, Almost Everyone Agrees that the U.S. Strikes Against Syria Are Illegal, Except Most Governments, OPINIO JURIS (Apr. 12, 2017), http://opiniojuris.org/2017/04/07/almost-everyone-agrees-thatthe-u-s-strikes-against-syria-are-illegal-under-international-law-except-for-most-governments [http://perma.cc/M4PE-TTJR].

192. Koh, War Powers, supra note 190 , at 980.

193. See Barack Obama, Nobel Lecture (Dec. 10, 2009) ("I believe that force can be justified on human- 
days following the U.S. response, the Trump Administration similarly declined to offer any meaningful analysis defending the legality of those missile strikes.

In the months ahead, the Administration's lawyers should correct that glaring omission and make clear when and under what circumstances the United States deems limited intervention for humanitarian purposes to be lawful and appropriate. As I have argued elsewhere, I would favor a test that does not preauthorize humanitarian intervention, but rather allows it to be asserted as an affirmative defense that would exempt actions that meet rigorous standards from legal wrongfulness. ${ }^{194}$ Whether or not you accept my test, we plainly need to articulate and agree upon a better rule to evaluate the legality of unilateral humanitarian intervention. ${ }^{195}$ As I have argued throughout this lecture, to build a smart-power solution, the United States must engage, translate, and leverage. To solve Syria, the United States must join other nationsincluding Russia - in building a sustainable peace process, organized around lawful conduct and a durable legal arrangement, and leverage that lawful core into a broader policy solution that contains and manages the sprawling crisis. In arguing for a public legal rationale for humanitarian intervention, my goal is not to have lawyers provide an excuse for unconstrained use of force in places like Syria. Rather, the goal is to make legally available the option of diplomacy backed by force, which would give greater leverage for meaningful diplomacy than diplomatic talk alone.

I do not believe that the claim that, absent a Security Council resolution, humanitarian intervention is never legally available under domestic or international law can be sustained as a matter of law or policy. This "never-never

itarian grounds, as it was in the Balkans, or in other places that have been scarred by war. Inaction tears at our conscience and can lead to more costly intervention later. That's why all responsible nations must embrace the role that militaries with a clear mandate can play to keep the peace."), https:/www.nobelprize.org/nobel_prizes/peace/laureates/2009/obama-lecture_en.html [http://perma.cc/NS2M-3MDW].

194. One can analogize this situation to the Good Samaritan principle in domestic tort law. Tort law rarely preauthorizes bystanders to use force for humanitarian motives, for fear that they will abuse this license. But if those bystanders do act in a careful fashion, for the limited purpose of preventing a significantly worse outcome, the law will hold them exempt from wrongfulness after the fact. In such cases, we fully recognize the tension that the conduct raises with the letter of the law but invoke an affirmative defense so as not to render socially desirable conduct illegal.

195. See also Harold Hongju Koh, Humanitarian Intervention: Time for Better Law, 111 AJL UNBOUND 287 (2017), https://www.cambridge.org/core/joumals/american-journal-of-internationallaw/article/humanitarian-intervention-time-for-better-law/05B23622D7C19B2B3BF4BD05D693BD0F [http://perma.cc/VS62-4VEE] (from which the discussion in text derives). Although some would argue instead that some forms of unilateral humanitarian intervention are "illegal but legitimate," that position seemed dubious nearly two decades ago-at the time of the Kosovo intervention - and even less acceptable now. I know of nowhere else in the field of human rights where we accept "illegal but legitimate" as the permanent judgment of history. We did not say, for example, that regrettably, same-sex marriage and interracial marriage were "illegal but legitimate." Instead, we moved to legalize them. We brought our very best lawyerly skills, craft, and commitment to bear in a concerted effort to make lawful what we believed to be morally legitimate. Not to do so simply corrodes respect for the rule of law. See Rebecca Ingber, International Law Is Failing $U s$ in Syria, JUST SECURITY (Apr. 12, 2017, 11:06 AM), https://www.justsecurity.org/39895/international-law-failing-syria [http://perma.cc/D2VH-XBWP]. 
rule" exhibits the absolutist, formalist, textualist, originalist quality Americans usually associate with the late Justice Antonin Scalia. It relies on absolutist readings of text, as those texts were "originally understood," claiming that a nation may not engage in unilateral humanitarian intervention because of prohibitive wordings of Article 2(4) of the U.N. Charter ${ }^{196}$ and Article I of the U.S. Constitution. ${ }^{197}$ But on inspection, this position cannot be sustained. In both cases, this simplistic, absolutist reading cannot be squared with state practice, inter-branch practice, or the broader object and purpose of the document the reader claims to be interpreting.

As a matter of international law, the never-never rule is inconsistent with the object and purpose of the U.N. Charter, whose broad purposes include "promoting and encouraging respect for human rights."198 The absolutist position would allow each of the five permanent members of the U.N. Security Council (P5) to commit genocide against their own citizens with no basis for another actor to intervene to protect the population at risk. It seems equally inconsistent for a P5 member like Russia to protect a client state like Assad's Syria when it commits war crimes and crimes against humanity against its own citizens by insulating that conduct from international law's condemnation through eight consecutive U.N. Security Council vetoes. To overcome the manifest rigidity of the never-never rule, state practice has offered many prominent counterexamples of de facto humanitarian intervention ${ }^{199}$ : IndiaBangladesh $^{200}$; Tanzania-Uganda ${ }^{201}$; Vietnam-Cambodia (Khmer Rouge); the U.S. and the U.K. creating no-fly zones over Iraq to protect the Kurds and the Shias ${ }^{202}$; and of course, NATO's famous Kosovo episode of the late 20th century. ${ }^{203}$ If we as international lawyers believe that international law should serve human purposes-including the protection of human rights, and not just the territorial sovereignty of states--then an immutable never-never rule cannot survive as the legal rule governing unilateral humanitarian intervention in

196. U.N. Charter art. 2(4) ("All Members shall refrain in their international relations from the threat or use of force against the territorial integrity of political independence of any state, or in any other manner inconsistent with the Purposes of the United Nations.").

197. U.S. CONST. art. I, $\S 8$, cl. 11 ("Congress shall have Power ... to declare war.").

198. U.N. Charter pmbl., art. 1.

199. See generally Michael W. DOYLE, THE QUeSTION OF INTERVENTION: JOHN STUART MiLl AND THE RESPONSIBILITY TO PROTECT 110 (2015) (explaining that since Kosovo, the R2P concept "has been invoked explicitly and implicitly, successfully and unsuccessfully, in cases ranging from Myanmar and Kenya in 2008 , to Guinea in 2009, and ... Libya in 2011"); ANNE ORFORD, INTERNATIONAL AUTHORTTY AND THE RESPONSIBILITY TO PROTECT (2011).

200. See Gary J. Bass, The Indian Way of Humanitarian Intervention, 40 YALE J. INT'L L. 227 (2015).

201. See Daniel G. Acheson-Brown, The Tanzanian Invasion of Uganda: A Just War? 12 INT'L THIRD WORLD STUD. J. \& REV. 1 (2001).

202. See Ryan Goodman, Humanitarian Military Options for Syrian Chemical Weapons Attack: "Illegal but Not Unprecedented", JusT SECURITY (Apr. 6, 2017, 9:56 AM),

https:/www.justsecurity.org/39658/humanitarian-military-options-syrian-chemical-weapons-attack-illegalunprecedented [http://perma.cc/NH2W-65PK].

203. See Koh, War Powers, supra note 190, at 976-80. 
the 21 st century. ${ }^{204}$

It seems similarly inconsistent with the design of the U.S. Constitution to say - in the face of a long history of consistent executive branch practice to the contrary - that a limited, unilateral executive strike genuinely motivated by humanitarian purposes constitutes a "war" that, constitutionally, Congress must always declare. As I have chronicled elsewhere, the Framers plainly intended to have a strong executive operating within a strong constitutional system capable of responding effectively to emergent external threats. ${ }^{205} \mathrm{Be}$ cause of the superior institutional capacity of the executive to respond, over time, inter-branch practice has inevitably shifted discretion to the President to respond in many bona fide emergency situations, eroding the domestic face of the never-never rule through institutional acquiescence.

As a policy matter, the never-never rule creates a bias for passivity that guts the possibilities for smart power-diplomacy backed by force of the kind that might motivate the initiation of a "Syrian Dayton" peace process to resolve the festering crisis. It promotes a bi-level bias toward inaction in the face of gross human rights abuses at both the international and domestic level. The consequences of that legal bias favoring passivity falls on innocent civilians and guts the possibilities for meaningful atrocities prevention. In the last five years, the only two times that Russia and Assad have been willing to engage seriously at the diplomatic table have happened when the United States credibly threatened force: President Obama's 2013 "red line" episode (which prompted the removal of a significant stockpile of chemical weapons) and 2017. Before the April 6 strikes, the U.S. Secretary of State had little diplomatic leverage: he could only say to Russia's President Putin and Foreign Minister Lavrov, "If you use chemical weapons on innocent Syrian civilians, we will use harsh language and introduce an U.N. Security Council Resolution that you can veto for the 9th time." But the lawful availability of the useof-force option would instead allow the Secretary of State to say credibly:

We and our allies are looking to establish a no-fly safe zone in southern Syria or a northern humanitarian corridor from Aleppo to Turkey, and we will enforce it, even against Russian planes. And because you were undeniably complicit in Assad's blatantly unlawful hiding and use of chemical weapons, we will call you out, unless you stand down and agree to abstain from a U.N. Security Council Resolution allowing our proposed policy solution.

Some claim that a humanitarian exception to the Charter would permit any state to invoke claims of treaty violation or regional instability to use unilateral executive force pretextually, in order to commit aggression based on a

204. In other areas, for example, state practice has helped nations to develop an elongated concept of the "imminence" prerequisite to the exercise of national self-defense. See text accompanying note 167.

205. See generally Harold HongJu KoH, The National Security Constitution: SHaring Power AFTER THE IRAN-CONTRA AFFAIR (1990). 
claimed need for humanitarian intervention. ${ }^{206}$ But surely, states can craft a legal rule that-particularly when applied to uncontested facts-can distinguish exceptional situations from pretextual justifications. At this point, there can be little doubt that Syria presents a situation of unusual and exceptional severity: the strikes were invoked pursuant to a century-old global prohibition against the use of chemical weapons in a situation where European and Middle Eastern stability have been genuinely threatened by the Syrian civil war and the ensuing refugee crisis. Others assert that legally permitting unilateral humanitarian intervention in exceptional circumstances will lead down a slippery slope. But the slippery slope runs both ways. As noted above, doing nothing in the face of horrific cruelty promotes a skewed bi-level policy bias toward passivity in the face of gross abuses. But able lawyers should be capable of developing narrow legal tests that hold harmless the running of red lights by ambulance drivers without granting broad license for abuse to ambulance chasers.

The most serious argument against my position comes from those international lawyers, in America and elsewhere, who don't trust Donald Trump and his Administration to get this right. As should be clear by now, I share this skepticism. But in the international order, there is only one United States, and regardless of who is its president, the U.S. plays a critical role as a balance wheel of the international system. What the first months of the new Administration have shown - particularly the repeatedly blocked Travel Ban and the uncompleted threats to withdraw from the Iran Nuclear Deal and the U.N. system - is that the United States is much bigger than Donald Trump. And this lecture has shown on many fronts that Donald Trump will shift on many aspects of his stated foreign policy aims if subjected to enough political pressure. $^{207}$

Our challenge as participants in transnational legal process is to keep the Trump Administration's feet to the fire; to demand a Syrian policy and strate$g y$, not just a set of military strikes; and to seek a pivot to a broader smartpower diplomacy that might resolve the underlying Syrian crisis. And if America's President is truly serious about pursuing such diplomacy, he would be wise to revise other aspects of his chaotic early foreign policy. In particular, he should withdraw his offensive Travel Ban 3.0; do a better job talking and listening to our allies and working with critical organizational partners like NATO and the European Union; dial back his bombastic rhetoric in situa-

206. See, e.g., Jack Goldsmith, The Constitutionality of the Syria Strike Through the Eyes of OLC (and the Obama Administration), LAWFARE (Apr. 7, 2017, 7:31 AM),

https://www.lawfareblog.com/constitutionality-syria-strike-through-eyes-olc-and-obama-administration [http://perma.cc/KW9M-W24V].

207. See Emily Holden et al., Trump, the Indecisive, PoLmco (Sept. 26, 2017, 5:04 AM), $\mathrm{http} / /$ www.politico.com/story/2017/09/26/trump-business-climate-indecision-243074 [http://perma.cc/QXS4-UET4]. 
tions of growing tension with hostile countries like North Korea; and be more careful about telling the truth and respecting our intelligence agencies, so that listeners will actually believe our government when, for example, we accuse Russia of complicity in Assad's April 6 chemical weapons strike. If he cannot make these adjustments on his own, concerted pressure from litigation, allies, and public opinion will be necessary to make him bend.

A final question is where to begin the process of articulating the lawful concept of humanitarian intervention. One obvious place would be before the Assembly of States Parties of the International Criminal Court, which in December 2017 will consider the long-contemplated completion of the crime of aggression. ${ }^{208}$ Many member states justifiably fear that an unnuanced adoption of the crime would chill or criminalize lawful humanitarian intervention, causing the great irony that ICC members could not use force to prevent the very genocide, war crimes and crimes against humanity that the Court was created to punish! Perhaps the best way forward would be for those member States who wish to ratify the "crime of aggression" amendments to do so with a simple "boilerplate" declaration that "By this ratification, we do not endorse treating lawful humanitarian intervention as criminal aggression." If made by enough key member States, and supported by other Rome Statute signatories like the United States, such a declaration would both allow the ICC to complete the crime of aggression, while continuing the collective search for global agreement on exactly what constitutes "lawful humanitarian intervention" and the lawful exercise of the Responsibility to Protect (R2P).

As for Syria, in the so-called "Astana process," the Russians have recently expressed receptivity to the notion that Iran, Russia, and Turkey would be guarantors of so-called "de-escalation zones" within Syria, and authorized to use any necessary force to prevent civilian harm within those zones. ${ }^{209}$ The proposal has many flaws: it does not mention chemical weapons, provide any legal rationale, or offer a credible group of guarantors. Nevertheless, it would make sense for the Trump Administration to seize on Russia's seeming concession that these "de-escalation zones" within Syria are both a legally and politically available policy option in search of a more durable solution.

Ultimately, solving the festering crisis in Syria will require far more sustained and coherent diplomacy than we have seen to date from this Administration. At this writing, Rex Tillerson has overseen a baffling and troubling

208. For a detailed analysis of this vexed question, see generally Harold Hongju Koh \& Todd D. Buchwald, The Crime of Aggression: The United States Perspective, 109 AM. J. INT'L 257, 277-92 (2015) (describing the many legal issues left after the ICC's 2010 Kampala Review Conference, particularly the competing theories of how the amendments finalizing the crime may enter into force and the debate over whether states ratifying the aggression amendments must "opt out" or "opt in" to the Court's jurisdiction over the crime of aggression). See also Koh, supra note 195.

209. Patrick Henningsen, The Astana Process: A Possible Solution to an Impossible Situation in Syria, 21 ST CENTURY WIRE (May 10, 2017), http://21stcenturywire.com/2017/05/10/the-astana-process-a-possiblesolution-to-an-impossible-situation-in-syria [http://perma.cc/CS88-TW5P]. 
diminution of the State Department career services. ${ }^{210}$ Surely, an institutional State Department populated by the kind of extraordinary U.S. diplomats who brought about Dayton, Paris, and the Iran Nuclear Deal is fully capable of finding and concluding creative, durable diplomatic solutions to problems like Syria. But what remains to be seen is whether this President and Secretary of State will give them the mandate and discretion to do so. As so often happens with respect to foreign policy, the questions going forward will not be about America's capability, but about its wisdom and will.

\section{WHAT'S AT STAKE}

Several important lessons emerge from this rapid tour d'horizon. America's observance of law, international and constitutional, is preserved not just by the federal political branches and the leaders who lead them at any particular time, but by an ongoing transnational legal process whose diverse stakeholders elected officials do not control. Institutional habits, once formed, prove surprisingly hard to break. With respect to international organizations and regimes, as the old song goes, breaking up is hard to do. And in the $21 \mathrm{st}$ century, the best way to produce good foreign policy outcomes remains Engage-Translate-Leverage, not Disengage-Black Hole-Hard Power.

When Donald Trump took office, he was faced with international and domestic rules that created a persistent default path to compliance with preexisting norms. Once in place, this body of law became a "guardrail" for politics, and early signs indicate that most of those guardrails are still holding. A new president cannot simply have his way. Domestic constituencies and interests with institutional authority to push back are doing so, as are foreign allies with shared interests in preserving rules of law within a painfully constructed international system. Government bureaucracies long devoted to pursuing solutions to climate change or promoting diplomacy in foreign policy do not turn on a dime. ${ }^{211}$ The United States has become deeply enmeshed in many multilateral regimes, and exit from those regimes is neither immediate nor easy. Most fundamentally, many Americans want what many of these regimes offer, whether it be a nuclear-free Iran or clean energy. So exit, if it is attempted, will be challenged by transnational actors committed to the de-

210. Robbie Gramer et al., How the Trump Administration Broke the State Department, FoREIGN POL'Y (July 31, 2017), http://foreignpolicy.com/2017/07/31/how-the-trump-administration-broke-the-statedepartment [http://perma.cc/AL82-7V5M].

211. Our robust federal bureaucracy has seen many political leaders come and go. Moreover, every U.S. government official, high or low, takes a solemn oath not to obey any particular President, but to uphold the Constitution and laws of the United States of America, including the "international law [that] is part of our law." The Paquete Habana, 175 U.S. 677, 700 (1900). When a country elects a leader that nearly every employee of the State Department, the Environmental Protection Agency, and the Departments of Justice and the Interior has voted against, those bureaucrats have myriad ways of saying "Yes, Minister": i.e., signaling political obedience while continuing along the previous bureaucratic path. See Harold Hongju Koh, The Next Four Years: A Thanksgiving Strategy, JUST SECURITY (Nov. 24, 2016, 8:32 AM), https://www.justsecurity.org/34868/years-thanksgiving-strategy-harold-koh [http://perma.cc/Y3FK-Z6RT]. 
fault agenda. And if exit and change are made difficult, the Administration will have to ask itself, "how critical, really, are these policy changes and institutional exits to the core agenda of this Administration?"

Whatever the new Administration may say to claim that it has fulfilled particular campaign promises, the real question is how much it really cares about any particular policy initiative, especially when those resisting, say, a religion-based Travel Ban are ready to fight back together against a radical policy change from both the inside and the outside. So even for an Administration that made many promises to win a tumultuous campaign, enough internal and external resistance to change can make the Administration's path of least resistance staying and underperforming in existing legal regimes, rather than absorbing the costs of actual violation of standing international rules and exit from standing international institutions.

In battling over all of these issues, what's really at stake? Our current system of Kantian global governance versus a cynical system of authoritarian spheres of influence. That is why we are potentially at such a dramatic moment of change. What is being rejected now is not just a prior administration's foreign policy strategy, but a broader political philosophy of international cooperation, of the kind that philosopher Immanuel Kant talked about in his great pamphlet Perpetual Peace. ${ }^{212}$ Significantly, Kant did not advocate world government; those who attack Kantian global governance as "world government" are attacking a straw man. What Kant declared instead was that "The Law of Nations Shall be Founded on a Federation of Free States"213: that law-abiding nations should live in a law-governed international society, where sovereign states that respect basic values-democracy, the rule of law, individual freedom, and the mutual advantages derived from peaceful intercourse-engage in mutual discourse based on respect for domestic and international rule of law in order to achieve shared outcomes. Or, otherwise put, Engage, Translate, and Leverage.

Kantian global governance is a system that the United States helped to create and sustain since World War II. It formed the basis for the United Nations - our system to end war and promote human rights - and the Bretton Woods system to govern international monetary flows, trade, and development through the IMF, WTO, and World Bank-our system to end global depression and poverty. Kantian global governance has allowed the United States to lead a group of like-minded nations to organize an ambitious multilateral assault on all manner of global problems: e.g., climate change, through the U.N. Framework Convention on Climate Change; intellectual property, through the World Intellectual Property Organization; and global health, through the World Health Organization. For more than seventy years, the

212. Immanuel Kant, Perpetual Peace: A Philosophical Sketch (1795)

213. Id. at $\S 2$, art. 2 . 
United States has been the driver, the balance wheel of this Kantian governance system, whether it be in the United Nations, the World Trade Organization, the Paris Climate Change Regime, or the Iran Nuclear Deal.

But as I speak, all of these historical experiments, as well as the Brexitled attack on the European Union, are under threat of displacement by a counter-model of Orwellian spheres of influence. Remember the nasty and brutish world that George Orwell described in his haunting book 1984: a world in which cynical global mega-powers - indistinguishable from one another in their authoritarianism, totalitarianism, and commitment to disinformation and "fake news"-violate human rights and the rule of law within their own spheres, while making cynical alliances and manipulating public opinion to make today's adversaries tomorrow's allies. ${ }^{214}$ Unlike Kant, Trump does not seem to believe in universal rights or accept the notion that everyone can rise together. His "America First" strategy, most recently repeated in his first United Nations speech, grimly views our interactions with the world as zerosum, an approach that inevitably promotes reciprocal self-centeredness on the part of other powerful nations.

Will we head in this Orwellian direction? Will Donald trump international law? Will he change the process or will it change him? Will consistent "rope-a-dope" resistance force him to adapt and change course in a more international law-friendly direction? And as his fragile coalition comes under stress, will it solidify or crumble?

The answer to all of these questions, of course, is "we shall see." But the early signs give reason for optimism. As this review has chronicled, in some issue areas, bold public acts of resistance are playing a critical role in blocking Trump's initiatives. In other areas, bureaucratic inertia, path dependence, overly high opportunity costs, and international realpolitik realities have posed powerful constraints. In many of these areas, both heroic and mundane constraints can be seen at work. But the revealed challenge for those who wish to join forces actively to resist is to search for, find, and apply political pressure to those critical pressure points within transnational legal process that can be strategically leveraged by anti-Trump actors.

Is the rope-a-dope working? While we are still in the early months of this Administration, here's the tally so far. Close to fifty executive orders with little real impact. Twenty senior officials resigned. Two stunning losses on repealing Obamacare. Travel Ban: thrice blocked in the lower courts. Torture order: never issued. Climate: a claimed withdrawal that will not go into effect until after the next presidential election. Iran Nuclear Deal: under siege, but still in place. North Korea: saber-rattling and rhetoric, but no real change in policy. Russian hacking: continued turmoil, many active investiga-

214. GEORGE ORWELL, 1984 (1961), 
tions, and indictments coming. Ukraine: mobilizing transnational legal process on its own. IS and Syria: borrowing from the Clinton playbook but lacking the "smart power" plan that might achieve durable outcomes. Many strained alliances, both with foreign governments and with Trump's Republican allies. Little progress on Trump's core agenda. And all of that less than a quarter way into a four-year term.

In closing, I am reminded of an old joke by comedian Mel Brooks, playing a 2000-year-old man. That super-elderly man is asked, "Before the Almighty, did you believe in any superior being?" His answer: "There was this guy, Phil; and we used to plead, 'Oh Phil, don't kick us; don't beat us; don't hurt us.' Until one day, lightning came out of the sky and struck Phil down. At which point we realized, 'There's something bigger than Phil!' "215

Well, in the same way, there's something bigger than Donald Trump. He does not own transnational legal process. He is just another player in it. What this lecture should remind you is that so are we, as are all the other transnational actors I have mentioned.

In sketching this picture, I am intensely mindful that the fight is just beginning. Inevitably, a "rope-a-dope" strategy wears down both sides. While the resistance has won impressive early victories, the constant battering by the Trump Administration may have a longer-term corrosive effect on the health and well-being of our democratic institutions. And while in Donald Trump's America, legal guardrails may be keeping the traffic of power more or less on the road of law, in other countries with weaker democratic institutions and civil society, the news is far darker. China, Russia, and illiberal democracies like Hungary, Poland, and Venezuela are emerging not just as spoilers of, but as active predators within, the liberal international order. Perhaps our postwar alliance system can preserve and continue to build the international order by keeping these illiberal states within the guardrails. But as I write, pressure on human rights activism is visibly growing, not just in these states, but in other democratic states throughout Europe, as well as India. The language of human rights and democratic sovereignty are increasingly being turned against the whole idea of external monitoring of domestic compliance with international law. ${ }^{216}$

So the game is on, and the stakes are high. The fight is in its early rounds, and the transnational legal saga is just beginning.

215. ZachsMind, Fave Jokes: 2000 Year Old Man, Wordpress: ZachsMind (Feb. 2, 2012), https://zachsmind.wordpress.com/2012/02/02/fave-jokes-2000-year-old-man [http://perma.cc/8NLQ-TBVB].

216. Compare President Trump's recent "sovereignty first" statements with Rohingyas Illegal Immigrants, Not Refugees: Rajnath, PRESS TR. OF INDIA (Sept. 21, 2017), http://www.ptinews.com/news/9089318 _Rohingyas-illegal-immigrants-not-refugees--Rajnath.html [http://perma.cc/YCX7-S4EX] (statement of Indian Home Minister) ("We have to think about the human rights of our own people before talking about the human rights of people from other countries,' he said. Any sovereign country, the minister said, was free to take a decision on what kind of action it should take against illegal immigrants. 'The issue of national security is involved with regard to illegal immigration which our country can't undermine,' he said."). 
As you all know from living here in Topeka, Kansas, the home of Brown v. Board - as Dr. Martin Luther King, Jr. used to remind us, the arc of history is long, but it bends toward justice. ${ }^{217}$ But it doesn't bend by itself. We are all participants in transnational legal process. So it is up to us, as the story of this Administration unfolds, to continue to fight to help the arc of history bend in the right direction.

Thank you all very much for listening.

217. Martin Luther King, Jr., "Where Do We Go from Here?" Annual Report Delivered at the 11 th Convention of the Southern Christian Leadership Conference in Atlanta, GA (Aug. 16, 1967), $\mathrm{http}: / /$ kingencyclopedia.stanford.edu/encyclopedia/documentsentry/where_do_we_go_from_here_delivered_ at_the_11 th_annual_sclc_convention/[http://perma.cc/8UGK-LDU6]. 
